\title{
Petrografia e litoquímica de rochas ferríferas na região central do estado do Rio Grande do Norte (Domínio Rio Piranhas - Seridó, NE da Província Borborema)
}

\author{
Petrography and lithochemistry of ferriferous rocks in Rio Grande do Norte central region \\ (Rio Piranhas - Seridó Domain, Borborema Province Northeast, Brazil)
}

\begin{abstract}
Alexandre Ranier Dantas ${ }^{1,2}$, Marcos Antônio Leite do Nascimento ${ }^{1}$, Alan Pereira da Costa ${ }^{2}$, Rogério Cavalcante ${ }^{2}$ ${ }_{1}^{1}$ Programa de Pós-graduação em Geodinâmica e Geofísica, Universidade Federal do Rio Grande do Norte - UFRN, Campus Universitário s/n, Lagoa Nova, Caixa Postal 1678, CEP 59078-970 Natal, RN, BR (alexandre.dantas@cprm.gov.br; marcos@geologia.ufrn.br) ${ }^{2}$ Núcleo de Apoio de Natal, Serviço Geológico do Brasil - CPRM, Natal, RN, BR. (alan.costa@cprm.gov.br; rogerio.cavalcante@cprm.gov.br)
\end{abstract}

Recebido em 18 de janeiro de 2017; aceito em 14 de agosto de 2017

\begin{abstract}
Resumo
As ocorrências de rochas ferríferas no estado do Rio Grande do Norte correspondem essencialmente a pequenos depósitos que aparentemente não apresentam potencial econômico. Porém, pequenos jazimentos desse bem mineral têm sido explotados em algumas áreas dessa região. As formações ferríferas ocorrem como intercalações decimétricas a algumas dezenas de metros em gnaisses da Formação Jucurutu e menos frequentemente estão associadas às rochas metamáficas encaixadas em gnaisses do Complexo Caicó. Neste trabalho, é apresentada uma caracterização petrográfica macro e microscópica de rochas ferríferas, além da discussão dos dados de litoquímica e uso de MEV-EDS para estudo da composição química qualitativa de magnetitas e anfibólios. Essas rochas normalmente apresentam teores de $\mathrm{Fe}_{2} \mathrm{O}_{3}$ variando entre 46 e $59 \%$ e de $\mathrm{SiO}_{2}$ entre 33 e 50\%. Petrograficamente, foram identificados dois grupos distintos: rochas ferríferas granulares e rochas ferríferas bandadas. A litoquímica permitiu concluir que os grupos de rochas estudadas apresentam comportamentos ora similares, ora distintos. São rochas compostas essencialmente de Si e Fe, com pequena proporção de elementos-traço e terras raras. Os parâmetros químicos indicam ambiente dominantemente oxidante e grupos de rochas em posições intermediárias a mais próximas das fontes hidrotermais oceânicas. Os ambientes tectônicos para formação das rochas ferríferas granulares e bandadas estudadas indicam principalmente cadeias oceânicas localizadas nas imediações de margens continentais ativas transicionais a arco de ilhas.
\end{abstract}

Palavras-chave: Formações ferríferas; Petrografia; Litoquímica; Faixa Seridó; Rio Grande do Norte.

\begin{abstract}
Ferriferous occurrences in the state of Rio Grande do Norte, Brazil, essentially correspond to small deposits without apparent economic potential, but small deposits of this mineral have been well exploited in some areas of this region. The iron formations occur as decimeters to tens of meters layers intercalated with the Jucurutu Formation gneiss, but less frequently, with metamafic rocks hosted in the gneiss from Caicó Complex. In this work, it is presented a macroscopic and microscopic petrographic characterization of banded iron rocks thin sections, besides the discussion of lithogeochemistry data and the use of MEV-EDS to study the qualitative chemical composition of magnetites and amphiboles. These rocks are formed by $\mathrm{Fe}_{2} \mathrm{O}_{3}$ content ranging between 46 and $59 \%$ and $\mathrm{SiO}_{2}$ content ranging between 33 and $50 \%$. Petrographically, there were identified two distinct groups: granular ferriferous rocks and banded iron rocks. The lithogeochemistry permited to conclude that groups of granular and banded iron rocks sometimes present a similar behavior, sometimes not. The rocks are mainly composed of $\mathrm{Si}$ and $\mathrm{Fe}$, with small proportion of trace and rare earths elements. The chemical parameters indicate dominantly oxidant environment and groups of rocks, since intermediate positions to closest the oceanic hydrothermal vents. The tectonic environments for the formation of granular and banded iron rocks studied indicate mainly oceanic chains located next to active continental margins transitional to island arc.
\end{abstract}

Keywords: Iron formations; Petrography; Lithochemistry; Seridó Belt; Rio Grande do Norte. 


\section{INTRODUÇÃO}

O estudo das formações ferríferas é importante não apenas por concentrarem a maior fonte econômica de ferro nas rochas, mas por serem particularmente essenciais para o entendimento da evolução atmosférica, a composição química dos oceanos e o surgimento de vida na Terra (Spier et al., 2007).

As ocorrências de formações ferríferas encaixadas em rochas correlatas à Formação Jucurutu e aquelas que ocorrem em rochas do embasamento gnáissico-migmatítico (correlatas ao Complexo Caicó) podem contribuir, através de petrografia e química de rocha, para o entendimento da evolução litosférica da região e de suas relações com sistemas mineralizantes, sejam eles magmáticos e/ou magmático-hidrotermais (depósitos vulcano-exalativos, de skarn, entre outros), ajudando na contextualização dessas ocorrências minerais dentro do Domínio Rio Piranhas-Seridó (DPS), na porção sententrional da Província Borborema (Angelim et al., 2006).

Duas áreas de estudo foram selecionadas - nordeste e sudoeste (Figura 1) - com base em projetos de mapeamento geológico executados entre os anos de 2009 e 2014 pelo Serviço Geológico do Brasil (CPRM). Um total de 15 afloramentos tiveram coleta de rochas para estudo de petrografia e litoquímica. Dados que estão sendo apresentados neste artigo.

Os objetivos principais deste trabalho compreendem:

- Realizar uma caracterização petrográfica macro e microscópica, incluindo análise química mineral semiquantitativa;

- Identificar o comportamento químico distinto entre as rochas ferríferas encaixadas nas rochas supracrustais (Formação Jucurutu) e no embasamento (Complexo Caicó);

- Analisar os elementos maiores buscando similaridades químicas com as formações ferríferas típicas, fazendo o estabelecimento de sua faciologia, na tentativa de contextualizar as formações ferríferas (FFs) do tipo Algoma ou Superior de Gross e McLeod (1980) e FFs do tipo Rapitan de Klein e Beukes (1993);

- Estudar a assinatura dos elementos-traço e terras raras para definição de protólitos e ambiente tectônico.

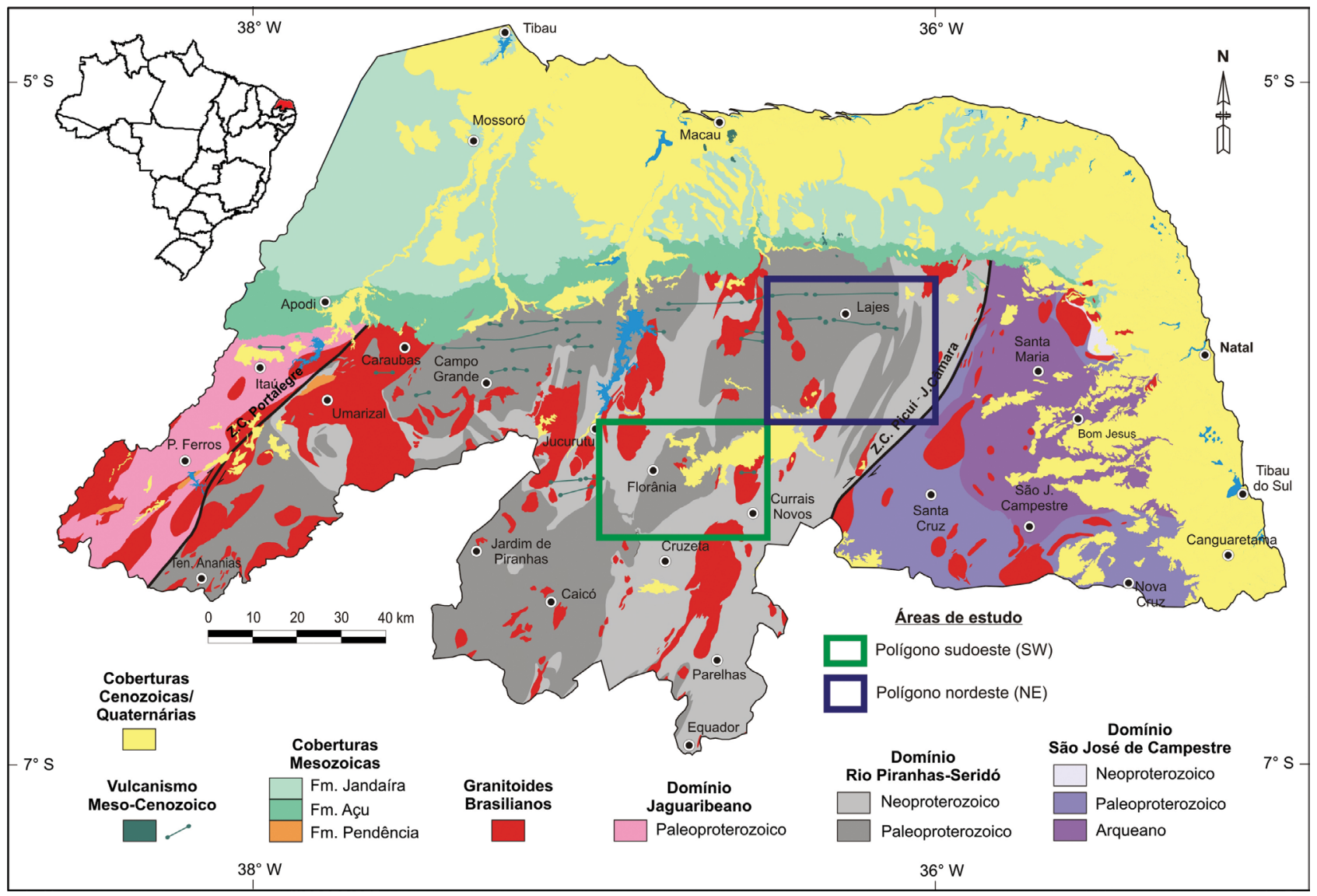

P. Ferros: Pau dos Ferros; Z. C.: zona de cisalhamento; Fm: Formação.

Figura 1. Compartimentação tectônica do estado do Rio Grande do Norte (Medeiros et al., 2010), com a localização das áreas de estudo (polígonos sudoeste e nordeste). 


\section{GEOLOGIA REGIONAL E DA ÁREA}

As áreas de estudo (Figura 1) estão situadas na porção leste do DPS. Segundo Angelim et al. (2006), o DPS corresponde à porção da Faixa Seridó de Jardim de Sá (1994) situada a oeste da zona de cisalhamento Picuí-João Câmara, ao Terreno Seridó de Campelo (1999) e aos terrenos Rio Piranhas e Faixa Seridó de Brito Neves et al. (2000). Está limitado tectonicamente a oeste pelo Domínio Jaguaribeano por meio da zona de cisalhamento Portalegre, considerada uma sutura transcorrente/transformante brasiliana, e a leste pelo Domínio São José do Campestre, por meio da zona de cisalhamento PicuíJoão Câmara. Compreende um embasamento, ora referido como Embasamento Rio Piranhas (ERP), e uma cobertura de rochas supracrustais correspondente à Faixa Seridó (FSE). Essas rochas são cortadas por corpos granitoides ediacaranos e rochas vulcânicas básicas relacionadas aos magmatismos Macau e Rio Ceará-Mirim. Na região, ainda ocorrem as coberturas sedimentares cenozoicas.

O ERP das rochas supracrustais é reportado por Jardim de Sá (1994) como ortognaisses equigranulares, ou augen, anfibólitos e rochas metavulcânicas e metassedimentares. Esses ortognaisses variam de gabro-diorítico a granítico, de quimismo cálcio-alcalino de alto potássio, com idade variando entre 2,25 e 2,15 Ga (Souza et al., 2007; Hollanda et al., 2011; Medeiros et al., 2012b), interpretados como derivados do manto enriquecido em um contexto de acresção crustal (Souza et al., 2007).

A Faixa Seridó corresponde às rochas supracrustais do Grupo Seridó, que é constituído por uma unidade basal formada principalmente por paragnaisses, com intercalações de mármores e rochas calciossilicáticas (Formação Jucurutu), uma intermediária composta por quartzitos e metaconglomerados (Formação Equador) e uma superior essencialmente constituída por micaxistos (Formação Seridó) (Jardim de Sá e Salim, 1980). Segundo Van Schmus et al. (2003), as datações U-Pb em zircões detríticos mostraram idades mínimas em torno de 650 Ma como provável idade para a deposição do Grupo Seridó. Hollanda et al. (2015) indicaram que a proveniência dos metapelitos no topo da sucessão metassedimentar que constitui o Grupo Seridó inclui uma população proeminente de zircões criogenianos com os grãos mais jovens datados entre 640 e $620 \mathrm{Ma}$. A deposição desse grupo teria cessado em $600 \mathrm{Ma}$, pela indicação de plutons graníticos intrusos nessas rochas.

As ocorrências de rochas ferríferas na região central do Rio Grande do Norte ocorrem como intercalações decimétricas a algumas dezenas de metros em gnaisses da Formação Jucurutu, na base do Grupo Seridó. Menos frequentemente estão associadas às rochas metamáficas encaixadas em gnaisses do Complexo Caicó e possíveis rochas ortoderivadas. Basicamente, nas regiões de estudo (Figura 1) é possível distinguir três tipos principais de rochas ferríferas:
- Ocorrências de formações ferríferas de provável origem sedimentar encaixadas na Formação Jucurutu;

- Formações ferríferas descontínuas encaixadas no embasamento paleoproterozoico (Complexo Caicó);

- Rochas metamáficas - metaultramáficas possivelmente relacionadas a depósitos (orto) magmáticos de óxidos de Fe-Ti.

Os dois primeiros casos são alvo deste estudo. São rochas compostas basicamente de quartzo, óxidos e hidróxidos de ferro, anfibólios (membros da série cummingtonita-grunerita e tremolita-actinolita), de granulação fina a média e textura dominante granonematoblástica, homogêneas ou com bandamento composicional.

Os mapas geológicos das áreas nordeste (Figura 2) e sudoeste (Figura 3) foram baseados principalmente em Medeiros et al. (2012a), Costa e Dantas (2014) e Cavalcante et al. (2015). Mostram a distribuição das rochas ferríferas no contexto da área de estudo.

\section{MATERIAIS E MÉTODOS}

A metodologia desenvolvida neste trabalho inclui revisão bibliográfica sobre o tema estudado, aquisição de amostras de rochas ferríferas para estudo de química de rocha e petrografia, estudo de lâminas delgadas e seções polidas e tratamento dos dados. As amostras de rocha foram adquiridas em afloramentos através de mapeamentos geológicos sistemáticos na escala de 1:100.000 e levantamento de recursos minerais das folhas Lajes e Currais Novos já executados pelo CPRM. Por meio desses mapeamentos, foi identificada uma quantidade significativa de ocorrências de rochas ferríferas (Dantas et al., 2012; Dantas e Costa, 2014), com o cadastramento de 48 ocorrências minerais. Neste trabalho foi coletado um total de 17 amostras para litoquímica e confecção de seções delgadas, polidas e lâminas polidas.

A pesquisa bibliográfica focou em trabalhos prévios existentes no âmbito do Rio Grande do Norte (Campos, 2011; Figueiredo, 2012; Silva Filho, 2012; Barbosa, 2013; Ferreira et al., 2015; Sial et al., 2015; Abrahão Filho, 2016), além de exemplos brasileiros e mundiais pesquisados simultaneamente.

As amostras de rocha coletadas foram enviadas para preparo e análise química de multielementos no laboratório da Analytical Laboratories Ltda. (ACME) e SGS Geosol Laboratórios Ltda. Em ambos os casos os elementos maiores, menores e traços foram analisados, após fusão por metaborato e digestão ácida (água régia), em espectrômetro de plasma acoplado (ICP-MS). Algumas amostras tiveram os óxidos analisados por fluorescência de raios X (XRF) após fusão por metaborato.

As lâminas delgadas, polidas e seções polidas foram descritas em microscópio óptico de luz transmitida e refletida 


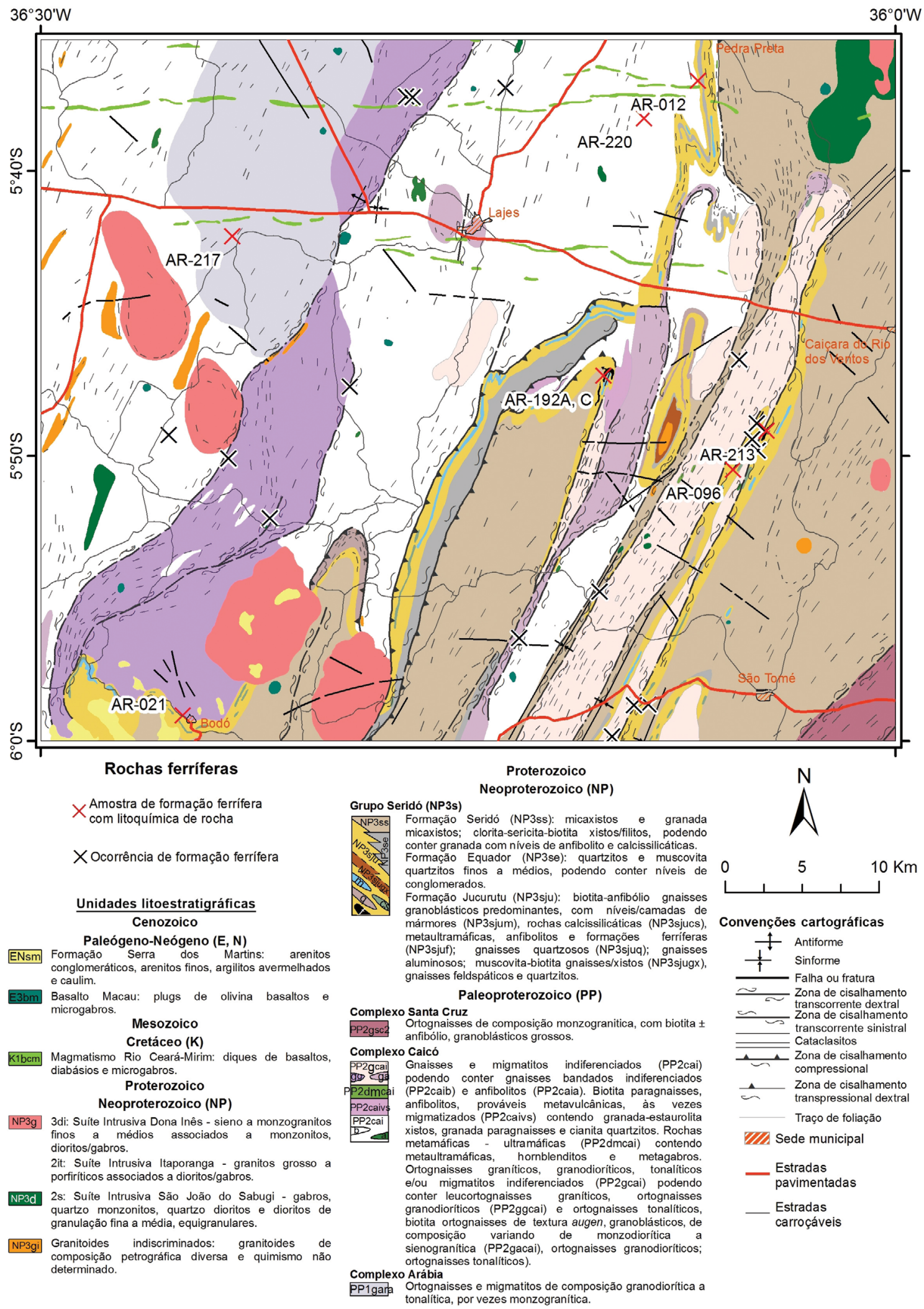

Fonte: compilado de Costa e Dantas (2014); Dantas e Costa (2014); Cavalcante et al. (2015).

Figura 2. Mapa geológico da área de estudo nordeste com a localização das ocorrências minerais de formação ferrífera e os pontos de ocorrências minerais com coleta de amostra para litoquímica. Datum WGS84, Zona 24-Sul. 


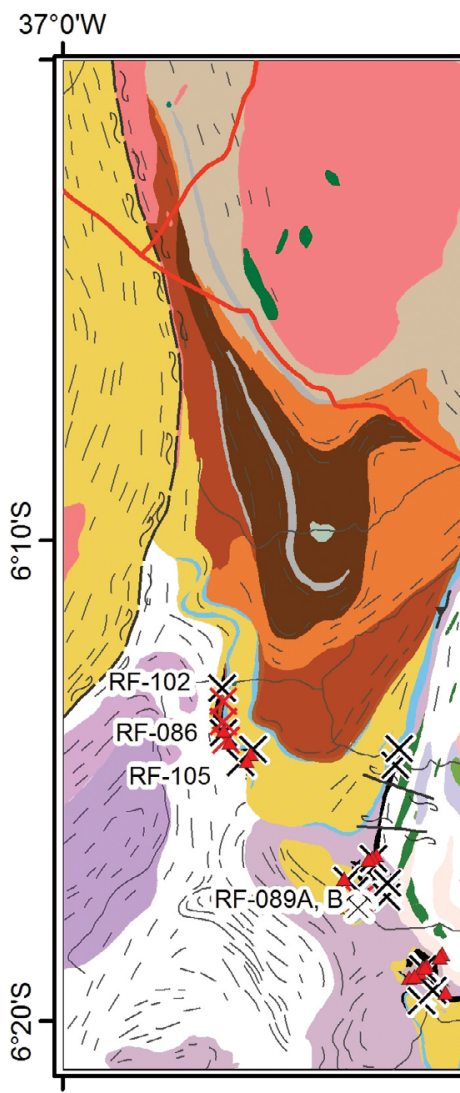

Unidades litoestratigráficas

\section{Cenozoico \\ Quaternário(Q)}

Q2a Depósitos aluvionares: areias, cascalhos e argilas. Paleógeno-Neógeno (E, N)

ENsm Formaç̃o Serra dos Martins: arenitos conglomeráticos, arenitos finos, argilitos avermelhados conglimeraticos, arenitos finos, argitos avermelhados

Basalto Macau: plugs de olivina basaltos e microgabros.

\section{Mesozoico}

Cretáceo (K)

K1bem

Magmatismo Rio Ceará-Mirim: diques de basaltos, diabásios e microgabros.

\section{Paleozoico}

Cambriano (e)

e12p Corpos e diques pegmatíticos.

egg Corpos e diques de sienogranitos e granodioritos.

\section{Proterozoico}

\section{Neoproterozoico (NP)}

NP3g 3di: Suite Intrusiva Dona Inês - sieno a monzogranitos finos a médios associados a monzonitos,

2it: Suite Intrusiva Itaporanga - granitos grosso a porfiríticos associados a dioritos/gabros.

2c: Suíte Intrusiva Conceição - granitos, granodioritos e tonalitos equigranulares finos a médios.

2s: Suite Intrusiva São João do Sabugi - gabros, quartzo monzonitos, quartzo dioritos e dioritos de granulação fina a média, equigranulares.

NP3gi Granitoides indiscriminados: granitoides de determinado.
Grupo Seridó (NP3s)

NP3ss Formação Seridó: micaxistos e granada micaxistos (NP3ss); clorita-sericita-biotita xistos/filitos, podendo conter granada; com niveis de anfibolito calcissilicáticas.

Formação Equador: quartzitos e muscovita quartzitos lepidogranoblásticos finos a médios de coloração cinza claro a creme (NP3se), podendo conter niveis d conglomerados.

Formação Jucurutu: biotita-anfibólio gnaisses granoblásticos (NP3sju) predominantes, com níveis/camadas de mármores (NP3sjum), rochas calcissilicáticas (NP3sjucs), metaultramáficas (NP3sjuu), anfibolitos (NP3sjua) e formações (NP3juu), anfolios (NP3jua) e rontzoes (NP3sjug); gnaisses aluminosos (NP3sjuga); muscovita-biotita gnaisses/xistos (NP3sjugx) gnaisses feldspáticos (NP3sjugf).

\section{Paleoproterozoico (PP)}

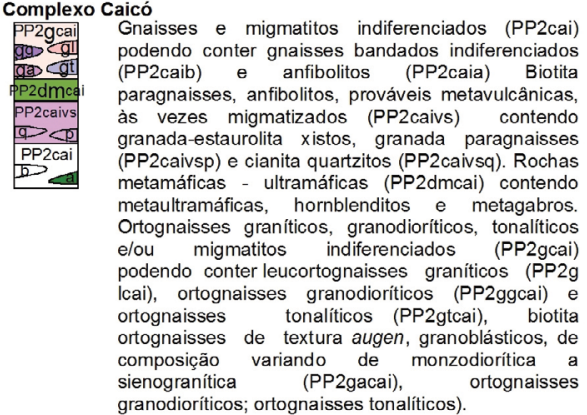

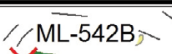
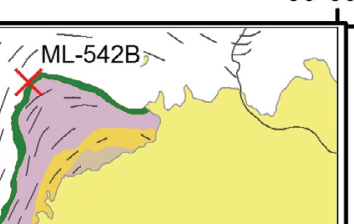
da marca Olympus BX-51 e software de captura de imagem Analysis, com lentes de aumento de 2 até 40x. Desse conjunto, um total de quatro lâminas bipolidas e duas seções polidas foi utilizado para identificação da composição química mineralógica dos tipos de anfibólios e de óxidos de ferro (magnetitas ou hematitas) por meio de microscópio eletrônico de varredura (MEV) e sistema de energia dispersiva (EDS).

Para a identificação através de imagens e análises químicas minerais semiquantitativas, respectivamente, com o uso do MEV e EDS, utilizou-se o equipamento de bancada TM3000 com o espectrômetro de energia dispersiva acoplado do modelo Quantax 70, ambos da Hitachi, no Departamento de Engenharia de Materiais (DEMAT) da Universidade Federal do Rio Grande do Norte (UFRN). As análises foram feitas com voltagem de 5 e $15 \mathrm{kV}$, filamento de tungstênio, $30 \mathrm{~nm}$ de resolução e leitura no EDS de 45 segundos por análise. Esse equipamento possui modo de redução de carga, que utiliza pressão de câmara mais elevada, permitindo a obtenção de imagens de amostras não revestidas.

Para o estudo de litoquímica, os dados de elementos maiores, traço e terras raras foram interpretados por meio de diagramas que reportam composição química e condições paleoambientais dos grupos de rocha analisados.

\section{RESULTADOS}

\section{Petrografia das formações ferríferas}

Um conjunto de dados de 18 lâminas delgadas, 5 lâminas delgadas polidas e 4 seções polidas de rochas ferríferas encaixadas no embasamento (Complexo Caicó) e Formação Jucurutu será apresentado neste item. Incluirá a descrição microscópica de ocorrências de formações ferríferas encontradas nos municípios de Lajes, Caiçara do Rio dos Ventos, São Tomé, Bodó e Santana do Matos, na porção nordeste da Faixa Seridó, além dos municípios de Cruzeta, Caicó e Florânia, na porção central da Faixa Seridó, todas no estado do Rio Grande do Norte e locadas respectivamente nas áreas de estudo nordeste (NE) e sudoeste (SW).

Dois grupos são separados macroscopicamente: formações ferríferas com aspecto mais homogêneo, de textura granular; $\mathrm{e}$ formações ferríferas tipicamente bandadas (Figura 4). Normalmente estão correlacionadas, respectivamente, às rochas encaixadas no Complexo Caicó e Formação Jucurutu, base do Grupo Seridó.

As rochas descritas neste trabalho normalmente apresentam uma foliação incipiente a penetrativa (Figura 4A). Em outras situações, o aspecto textural da rocha parece maciço, homogêneo (Figura 4B e Figura 4C). Poderiam ser
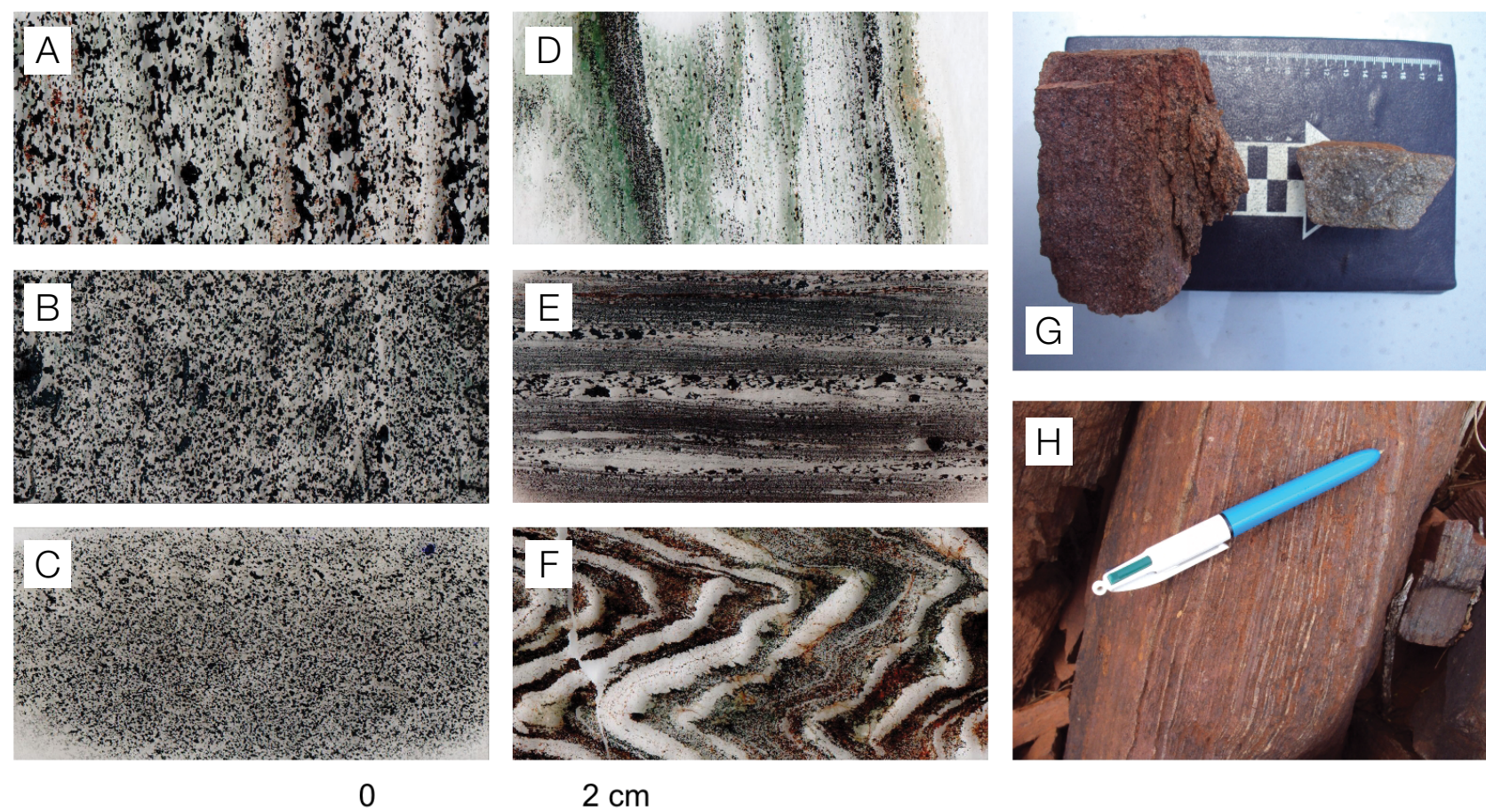

$2 \mathrm{~cm}$

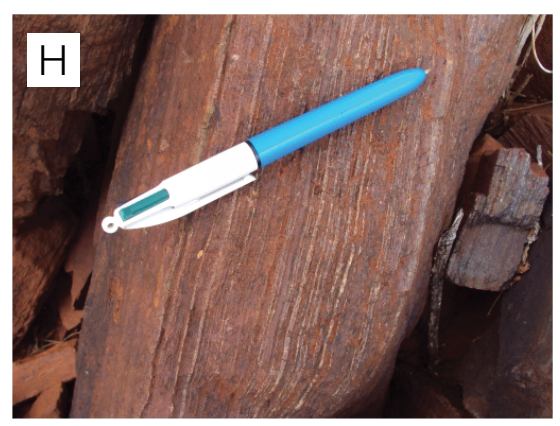

0

: (A) AR-R-012; (B) EL-16A; (C) RF-035; (D) AR-R-096; (E) RF-102; as formações ferríferas granulares. Os itens D, E, F e H são as formações ferríferas bandadas. Em transparente destaque para os níveis de quartzo, grãos e níveis em preto são os minerais opacos (magnetita e/ou hematita) e esverdeados são os anfibólios. 
classificadas como formação ferrífera granoblástica, considerando esse aspecto textural tão marcante. Porém, Trendall (2002) sugere o uso do termo formação ferrífera granular (FFG ou GIF, em inglês) como unidade litológica, assim como formações ferríferas bandadas (FFB ou BIF, em inglês), que é uma denominação clássica.

\section{Rochas ferriferas granulares}

Em escala de mão, as rochas ferríferas granulares apresentam coloração cinza escuro a preta, com pontos esbranquiçados. Ora com estrutura foliada visível, ora pouco visível. Apresentam textura granoblástica a nematogranoblástica (Figura 5A), com granulometria fina a média, mais raramente grossa. As condições metamórficas são estimadas em fácies xisto verde superior a anfibólito inferior, envolvendo a cristalização de anfibólios e biotita. São compostas por quartzo (45 a 55\%), anfibólios (5 a 10\%) de cores esverdeadas, amarronzadas e menos frequente incolores, minerais opacos (40 a 45\%) ocorrendo como cristais isolados intergranulares ou formando agregados e hidróxidos de ferro $(<1 \%)$ crescendo sobre minerais opacos e anfibólios, por vezes na matriz da rocha ou, ainda, em fissuras que cortam alguns cristais. Biotita e apatita ocorrem como traço em apenas duas amostras do grupo de formações ferríferas granulares.

No grupo de amostras estudadas, a grande maioria apresenta pouco (até $10 \%$ ) ou nenhum anfibólio. Porém, em duas amostras os anfibólios constituem entre 15 e 25\% dos minerais da formação ferrífera granular. Nesses casos, é comum a presença de anfibólio substituindo a magnetita, produzindo localmente a textura poiquiloblástica com inclusões de minerais opacos e quartzo. O inverso também ocorre, justificando o intercrescimento de minerais opacos versus anfibólio.

As seções polidas indicam que grande parte dos minerais opacos é hematita, com magnetita subordinada. A martitização (oxidação da magnetita para hematita) da magnetita é intensa (Figura 5B) e invade os cristais pelas bordas e fraturas, deixando restos de magnetita inalterada apenas no núcleo dos cristais.

Considerando as relações minerais observadas, sugerem-se as seguintes assembleias em ordem cronológica, a partir da mais antiga:

- Minerais opacos (magnetita) + quartzo + anfibólio + biotita + apatita (foliação);

- Minerais opacos (magnetita + hematita) + quartzo + anfibólio (crescimento tardi- a pós-foliação);

- Quartzo + minerais opacos (magnetita + hematita) (exsudados);

- Hidróxidos de ferro (matriz e fissuramento).

\section{Rochas ferríferas bandadas}

Macroscopicamente são rochas mesocráticas, de cor cinza escuro a preta, finas a grossas, de estrutura foliada e bandada.
O bandamento é milimétrico, do tipo claro (predominantemente quartzo) e escuro (minerais de ferro + quartzo) (Figura 5C). As bandas claras variam de 1 a $5 \mathrm{~mm}$; as bandas escuras apresentam de 1 a $3 \mathrm{~mm}$, em média. Por vezes os anfibólios estão mais concentrados em algumas faixas (Figura 5C), formando bandas de coloração esverdeada, exibindo textura nematoblástica, enquanto as faixas mais ricas em quartzo ou minerais opacos exibem uma textura granoblástica. Apresentam dois conjuntos de formações ferríferas bandadas baseados apenas no percentual de anfibólios. São compostas de quartzo (30 a 40\%), anfibólio entre 20 e $30 \%$ em um conjunto de amostras e em outro não ultrapassa $5 \%$ ou é ausente, de cores variando de incolores a esverdeadas ou azuladas claras, além de minerais opacos ( 30 a $55 \%$ ) formando agregados e também como cristais isolados. Muscovita e apatita ocorrem como mineral traço $(<1 \%)$.

Em algumas amostras, a tremolita-actinolita pode representar a maioria dos anfibólios presentes, constituindo de 10 até $25 \%$ da composição modal da rocha. A tremolita-actinolita fibrosa pode, ainda, ocorrer intercrescida com cristais aciculares de grunerita incolor, com maclas polissintéticas, tanto em cristais finíssimos situados em meio ao quartzo das bandas quartzosas, como em cristais de feixes maiores (até $1 \mathrm{~mm}$ de comprimento) junto às bandas de magnetita. Mostra alteração forte para material ferruginoso (goethita), particularmente ao longo das bordas e clivagens de alguns cristais.

Hematita em quantidade um pouco maior do que magnetita é o mineral opaco mais comum identificado nas seções polidas. Os cristais de magnetita mostram uma martitização moderada (Figura 5D), a partir da textura em treliça onde a hematita invade a magnetita a partir das bordas e se dispõe segundo as direções cristalográficas da magnetita.

As porções maciças de formações ferríferas bandadas chegam até $80 \%$ de minerais opacos, com menor proporção de quartzo (até $15 \%$ ), anfibólio (5\%) e hidróxidos de ferro $(<1 \%)$, como o caso da amostra HS-007A da mina de ferro de Saquinho (Figuras 5E e 5F). Apresentam particularmente uma quantidade expressiva de hematita especular (especularita) (Figura 5E), com menor proporção de magnetita, que ocorre associada ou inclusa nesse mineral (Figura 5F). Identifica-se no mínimo duas fases de cristalização de especularita quando a formação ferrífera está dobrada. Um grupo de cristais alinha-se segundo a superfície Sn (níveis dobrados), enquanto outros cristais alinham-se segundo a superficie $\mathrm{Sn}+1$ de plano axial (Figura 5E).

Associadas aos minerais opacos, observam-se estruturas avermelhadas de hábito acicular, orientadas ao longo da foliação, contato de fases minerais e no preenchimento de microfraturas. Provavelmente são hidróxidos de ferro (goethita) $(<2 \%)$ e argilominerais preenchendo planos de foliação.

$\mathrm{Na}$ amostra AR-021, foi observado até $20 \%$ de microclínio, de granulação fina. $\mathrm{O}$ mineral exibe maclas em xadrez mal definidas e apresenta leve alteração para argilominerais 

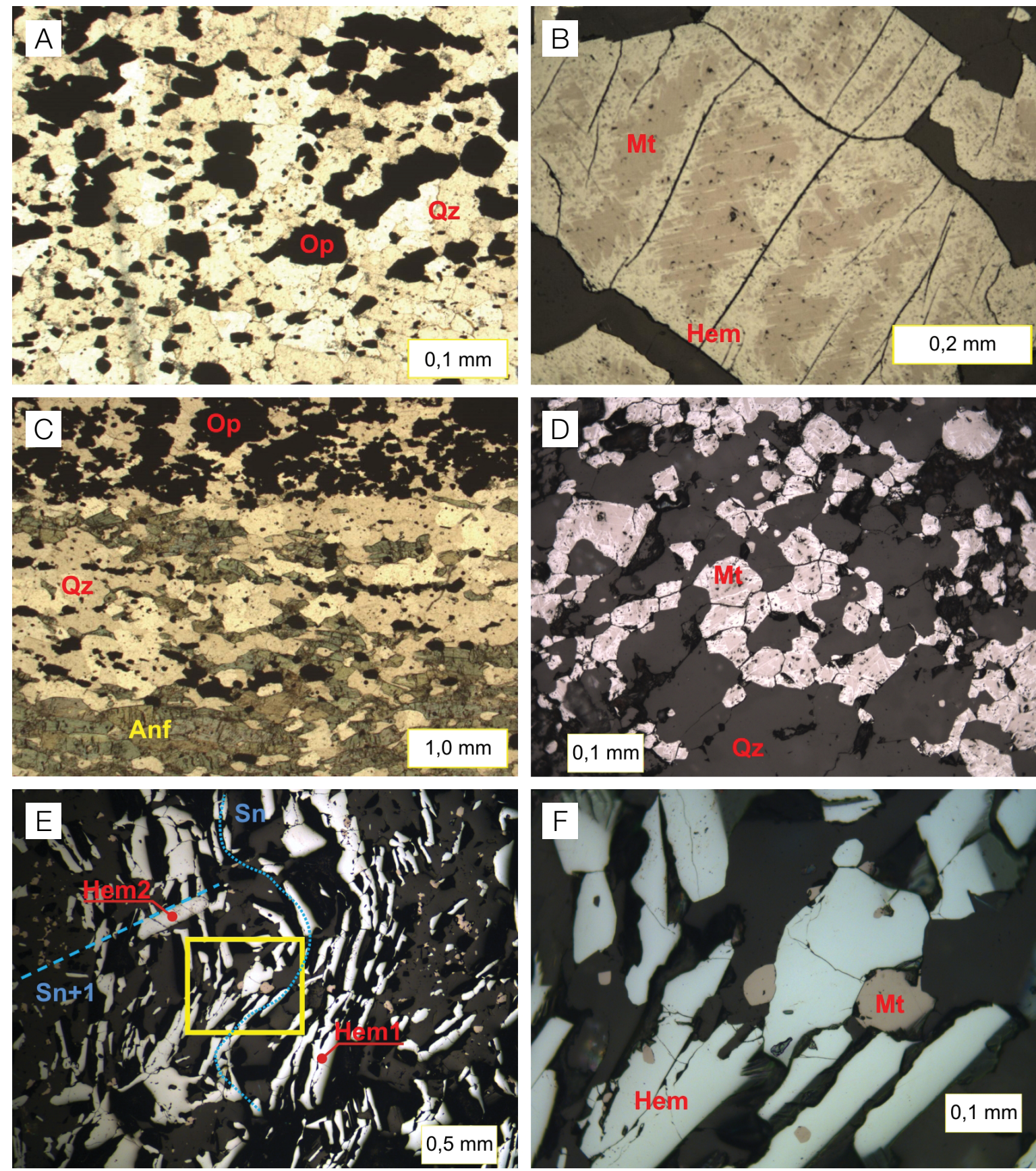

Op: opacos; Qz: quartzo; Mt: magnetita; Hem: hematita; Anf: anfibólio; Sn: foliação n; Hem1: hematita 1; Hem2: hematita 2; Sn+1: foliação Sn+1.

Figura 5. (A) Fotomicrografia da amostra AR-R-217A em lâmina delgada e nicóis paralelos mostrando a formação ferrífera granular com os minerais opacos disseminados em contato com cristais de quartzo; (B) fotomicrografia de lâmina delgada polida da amostra AR-R-217A de formação ferrífera granular com luz refletida de cristais de magnetita bastante transformados para hematita nas bordas e ao longo de fraturas, no padrão em treliça típico de martitização; (C) fotomicrografia de formação ferrífera bandada da amostra AR-R-096 em lâmina delgada e nicóis paralelos alternando banda milimétrica rica em quartzo de cor branca, anfibólios de cor esverdeada e de minerais opacos de cor preta. As bandas são fortemente orientadas e alongadas na direção da foliação; (D) fotomicrografia da amostra AR-R-192C de formação ferrífera bandada em seção polida com luz refletida composta essencialmente de quartzo e magnetita martitizada; (E) fotomicrografia da amostra de formação ferrifera bandada HS-007A da mina de Saquinho em seção polida com luz refletida rica em hematita especular em duas gerações de cristalização. O polígono amarelo é o detalhe apresentado na foto F; (F) fotomicrografia da amostra de formação ferrífera bandada HS-007A em seção polida com luz refletida de cristais xenoblásticos de magnetita associados ou inclusos em cristais de hematita especular. 
e impregnação por hidróxido de ferro (goethita) ao longo das bordas e clivagens.

Considerando as relações minerais observadas, sugerem-se as seguintes assembleias em ordem cronológica, a partir da mais antiga:

- Minerais opacos (magnetita + hematita) + quartzo + anfibólios + muscovita (foliação Sn);

- Minerais opacos (magnetita + hematita) + quartzo + anfibólios (plano axial $\mathrm{Sn}+1$ );

- Quartzo + minerais opacos (magnetita + hematita) (exsudados);

- Hidróxidos de ferro (fissuramento e intemperismo?).

Os anfibólios não deverão ser considerados nas relações das assembleias minerais descritas acima quando forem referidas as formações ferríferas que não apresentam esse mineral na sua composição mineralógica.

\section{Análises de microscópio eletrônico de varredura e sistema de energia dispersa}

Foram obtidas imagens de MEV dos elétrons retroespalhados (BSE) dos três minerais essenciais (quartzo, óxidos de ferro e anfibólios) que ocorrem nas rochas ferríferas da área de estudo. Os cristais de óxidos de ferro (magnetita ou hematita) apresentaram tons de cinza claro, os grãos de anfibólios com cor cinza de tom intermediário e os grãos de quartzo com tom de cinza escuro. Os resultados analíticos semiquantitativos do EDS estão apresentados na Tabela 1 em composição química por elemento, com a disposição dos dados de concentração elementar em percentagem de peso de anfibólios, óxidos de ferro e anfibólios alterados com hidróxidos de ferro, todos agrupados em formações ferríferas granulares ou bandadas. O EDS não diferencia os óxidos de ferro (magnetita e hematita).

Para melhor interpretação dos dados de EDS foi realizada a estequiometria dos resultados, transformando os dados elementares em óxidos. Os anfibólios foram normalizados para 23 oxigênios e classificados de acordo com a ocupação dos seus sítios iônicos. Posteriormente, foram classificados segundo a quantidade de iôns de sílica $(\mathrm{Si})$, a razão $\mathrm{Mg} /\left(\mathrm{Fe}^{+2}+\mathrm{Mg}\right)$ e a soma dos íons de cálcio $(\mathrm{Ca})$ e sódio $(\mathrm{Na})$ na posição $\mathrm{B}$ da fórmula padrão dos anfibólios de acordo com Leake et al. (1997).

A Tabela 2 apresenta a classificação dos anfibólios que ainda foi corroborada pelo banco de dados de espectrogramas e difratogramas de espécies minerais brasileiras em Sampaio (2016), além da composição química mineral constante no site Webmineral (http://www.webmineral.com/), que contém mais 4.700 registros de espécimes minerais.

Através da química mineral, não foi possível individualizar os tipos texturais de formações ferríferas. Os minerais analisados nas formações ferríferas granulares e bandadas

Tabela 1. Resultado da química elementar semiquantitava de cristais de anfibólios, anfibólios alterados com hidróxidos de ferro e óxidos de ferro adquirido no EDS para rochas ferríferas granulares e bandadas da área de estudo. Dados em concentração normatizada em percentagem de peso.

\begin{tabular}{lccccccccccccc}
\hline $\begin{array}{l}\text { Formação } \\
\text { ferrífera }\end{array}$ & Amostra & Mineral & O & Si & Ti & Al & Fe & Mn & Mg & Ca & Na & K & Total \\
\hline Granular & AR-012 & Anf 1 & 43,60 & 26,60 & & 0,77 & 10,30 & & 10,12 & 8,60 & & & 100 \\
Granular & AR-012 & Anf 2 & 44,01 & 26,30 & & 0,72 & 9,37 & & 8,98 & 10,63 & & & 100 \\
Granular & AR-217A & Anf 1 & 39,92 & 23,69 & & 0,49 & 25,80 & 1,76 & 7,53 & 0,65 & 0,14 & 0,03 & 100 \\
Granular & AR-217A & Anf 2 & 41,11 & 16,60 & & 0,17 & 15,37 & 3,23 & & 19,49 & 0,06 & 3,97 & 100 \\
Bandada & AR-192C & Anf 1 & 43,00 & 33,29 & & 5,28 & 14,32 & & 1,93 & 2,18 & & & 100 \\
Bandada & AR-192C & Anf 2 & 42,19 & 24,87 & & 2,25 & 16,49 & & 5,55 & 8,63 & & & 100 \\
Bandada & AR-213 & Anf 1 & 42,17 & 24,15 & 0,44 & 0,90 & 17,07 & 0,85 & 6,34 & 7,82 & 0,16 & 0,10 & 100 \\
Bandada & AR-213 & Anf2 & 40,31 & 19,59 & 2,89 & 0,41 & 15,15 & 2,88 & 3,04 & 12,34 & 0,26 & 3,13 & 100 \\
Granular & AR-012 & Anf+Hfe & 36,00 & 19,38 & & 1,56 & 40,25 & & 1,90 & 0,92 & & & 100 \\
Granular & AR-217A & Anf+Hfe & 42,04 & 23,71 & & 0,56 & 31,11 & 1,25 & & 0,69 & 0,33 & 0,30 & 100 \\
Granular & RF-035 & Anf+Hfe & 38,87 & 12,64 & & 4,13 & 41,56 & 0,71 & 0,63 & 0,68 & 0,47 & 0,30 & 100 \\
\hline Granular & AR-012 & Mag/Hem 1 & 28,25 & 1,18 & & & 70,24 & & 0,28 & 0,05 & & & 100 \\
Granular & AR-012 & Mag/Hem 2 & 28,00 & 1,65 & & 0,18 & 69,84 & & 0,33 & & & & 100 \\
Granular & AR-217A & Mag/Hem & 27,41 & 1,36 & & 0,15 & 68,72 & 1,08 & & 0,62 & 0,43 & 0,23 & 100 \\
Granular & RF-035 & Mag/Hem & 25,71 & 1,82 & & 0,09 & 70,90 & 1,01 & 0,09 & 0,13 & 0,24 & & 100 \\
Bandada & AR-192C & Mag/Hem 1 & 29,60 & 1,72 & & 0,12 & 68,49 & & & 0,06 & & & 100 \\
Bandada & AR-192C & Mag/Hem 2 & 30,15 & 2,56 & & 0,18 & 66,24 & & 0,56 & 0,31 & & & 100 \\
Bandada & AR-213 & Mag/Hem & 32,23 & 1,68 & 0,01 & 0,17 & 64,70 & 0,87 & 0,26 & 0,07 & & & 100 \\
Bandada & HS-007A & Mag/Hem & 23,20 & 0,80 & 0,29 & 0,75 & 72,93 & 1,08 & 0,02 & 0,00 & 0,47 & 0,45 & 100 \\
\hline
\end{tabular}

Anf: anfibólio; Anf+Hfe: anfibólios alterados com hidróxidos de ferro; Mag/Hem: óxidos de ferro (magnetita ou hematita). 
ocorrem como anfibólios cálcicos (actinolita, ferro-actinolita e ferro-edenita), com menor proporção de anfibólios ferromagnesianos e manganesíferos (grunerita). Apenas o cristal Anf 1 da amostra AR-192C não se aplicou à classificação de Leake et al. (1997), porém sua composição química é muito próxima da ferroholmquistita, que apresenta lítio em sua composição, mas não é um elemento químico identificado no EDS. O equipamento não faz a leitura desse elemento químico, pois apresenta um número atômico baixo, não detectável por essa técnica (Dedavid et al., 2007).

Os anfibólios alterados com hidróxido de ferro (Tabela 1) não foram classificados, mas percebe-se claramente o enriquecimento de ferro provocado por alterações minerais, com o crescimento de hidróxido de ferro, em comparação com a química mineral apresentada pelos anfibólios não alterados.

Os óxidos de ferro apresentam composição similar com magnetitas em ambos os tipos de formações ferríferas (granulares e bandadas) com muito baixo percentual de sílica e traços de alumínio, magnésio, cálcio e muito pouco manganês, titânio, sódio e potássio.

\section{Associações minerais e paragênese}

Na região das áreas de estudo, considerando a mineralogia, a textura, a estrutura e a composição química mineral já discutidas em itens anteriores, as rochas ferríferas apresentam composição relativamente simples, dominando principalmente quartzo, magnetita, hematita e anfibólios. Nas rochas ferríferas granulares, normalmente é menor o percentual de anfibólios em comparação com as rochas ferríferas bandadas, que contêm um percentual mais variado. Dentre as características mineralógicas apresentadas, percebe-se que as formações ferríferas estudadas correspondem a facies óxido de James (1954); porém, com componente silicática para os termos rochosos com maior percentual de anfibólios. Raposo (1996) faz referência a uma ocorrência de formação ferrífera metamórfica fácies óxido com uma forte componente silicática para um tipo litológico com grunerita como um dos constituintes essenciais da rocha.
Essa característica também é observada nas rochas ferríferas granulares e bandadas das áreas de estudo.

As associações minerais observadas são comuns aos dois grupos de rochas estudados. O crescimento de grãos de quartzo ocorre associado a cristais de magnetita e anfibólios, mesmo quando o bandamento milimétrico típico da formação ferrífera bandada mostra a concentração de níveis mais ricos em quartzo, minerais opacos (magnetita e hematita) e anfibólios intercalados. As relações de inclusões minerais são variadas, pois esses três minerais (quartzo, opacos e anfibólios) ocorrem como inclusões uns dos outros, indicando um crescimento contínuo durante o metamorfismo.

Considerando a natureza isoquímica do comportamento das formações ferríferas durante o metamorfismo, com perda apenas de voláteis (Klein, 1983) em reações de desidratação e descarbonatação (Klein, 2005), as rochas ferríferas da região central do Rio Grande do Norte apresentam associações minerais de rochas ferríferas de grau metamórfico médio. Nesse caso, em temperaturas que variam de 450 até $550^{\circ} \mathrm{C}$ e pressões que variam de 2 até 5 kbar (James, 1955; Haase, 1982a).

Nas rochas ferríferas, o quartzo, a magnetita e a hematita apenas se recristalizam e aumentam os tamanhos dos cristais com as condições crescentes de temperatura e pressão (James, 1954; Klein, 1973). Raposo (1996) afirma que as formações ferríferas não têm o mesmo comportamento que as rochas argilosas quando submetidas a elevações de temperatura e pressão, sobretudo nas faixas de temperaturas mais baixas. Alguns tipos, como os da fácies óxido ou da subfácies magnetita, constituídas essencialmente ou inteiramente por quartzo e magnetita, não sofrem nenhuma transformação mineralógica com o metamorfismo progressivo. Ocorre apenas um aumento do tamanho dos grãos de quartzo e magnetita.

No caso dos anfibólios, os minerais membros das séries cummingtonita-grunerita e tremolita-actinolita ocorrem em associação, tanto nas formações ferríferas bandadas como nas formações ferríferas granulares da região central da Faixa Seridó. Esse tipo de associação é comum em rochas

Tabela 2. Resultado da classificação dos anfibólios segundo Leake et al. (1997) obtidos a partir da análise química elementar semiquantitava de cristais de anfibólios adquirida no EDS para rochas ferríferas granulares e bandadas da área de estudo.

\begin{tabular}{lccc}
\hline Formação ferrífera & Amostra & Mineral & Classificação de anfibólios de Leake et al. (1997) \\
\hline Granular & AR-012 & Anfibólio - Cristal 1 & Actinolita \\
Granular & AR-012 & Anfibólio - Cristal 2 & Actinolita \\
Granular & AR-217A & Anfibólio - Cristal 1 & Grunerita manganesífera \\
Granular & AR-217A & Anfibólio - Cristal 2 & Ferro-edenita potássica \\
\hline Bandada & AR-192C & Anfibólio - Cristal 1 & Ferroholmquistite (?) \\
Bandada & AR-192C & Anfibólio - Cristal 2 & Ferro-actinolita \\
Bandada & AR-213 & Anfibólio - Cristal 1 & Ferro-actinolita \\
Bandada & AR-213 & Anfibólio - Cristal 2 & Ferro-edenita manganesífera-tinanífera-potássica \\
\hline
\end{tabular}


ferríferas quando as rochas pretéritas apresentam carbonato. Haase (1982b), através de estudos analíticos, afirma que essas assembleias de coexistência de actinolita e grunerita ocorrem em médio grau metamórfico $\left(400\right.$ a $\left.500^{\circ} \mathrm{C}\right)$ e na presença de fluidos ricos em água e $\mathrm{CO}_{2}$.

Grande parte da hematita nas rochas estudadas ocorre como produto de martitização. A presença escassa de hidróxidos de ferro, como goethita, por exemplo, denota a ideia de que as alterações intempéricas não foram muito atuantes na região. Sendo assim, essas hematitas das rochas ferríferas da região central do Rio Grande do Norte, especificamente produto de martitização, podem ser relatadas não como evidência de lixiviação. Klein (1983) sugere que essa substituição ocorre durante o metamorfismo regional e que não está relacionada com posterior oxidação supergênica de minérios de ferro. Halos de hidróxidos de ferro ocorrem em pouca proporção, envolvendo os grãos minerais de quartzo, opacos (magnetita e hematita) e anfibólios.

Após essas discussões sobre a cristalização mineral em rochas ferríferas desde diagênese até condições metamórficas de médio grau (fácies xisto verde e anfibolito), considerando as espécies minerais, as abundâncias e as relações entre elas, em condições de metamorfismo e pós-metamorfismo (hidrotermalismo ou intemperismo), foi possível sugerir uma paragênese mineral (Tabela 3) para os dois grupos de rochas ferríferas da área de estudo.

Em ambos os tipos de rocha (formação ferrífera granular e bandada) existe estreita relação no crescimento simultâneo de quartzo, magnetita e anfibólios (membros da série cummingtonita-grunerita e tremolita-actinolita). Hematita como produto de martitização provavelmente foi originada durante a evolução do metamorfismo à medida que água foi liberada nas reações metamórficas. No caso das formações ferríferas bandadas, foi possível observar uma segunda geração de magnetita, hematita e anfibólios da série cummingtonitagrunerita e tremolita-actinolita cristalizados paralelos aos planos axiais de dobras geradas durante o metamorfismo progressivo que atingiu as áreas de estudo.

\section{Geoquímica das formações ferríferas}

Para análise dos dados químicos das rochas ferríferas nas áreas de estudo (polígonos nordeste e sudoeste) foi utilizado um grupo de 17 amostras e os resultados estão apresentados na Tabela 4. A amostra RF-089A da Mina de Saquinho é de uma porção de minério de ferro maciço ( $>67 \%$ de $\mathrm{Fe}$ ) do pacote de formação ferrífera bandada. Através da litoquímica, é possível observar o comportamento elementar das formações ferríferas granulares e bandadas, buscando suas similaridades ou diferenças. Nesse sentido, os gráficos apresentados serão divididos em formações ferríferas granulares e bandadas.

\section{Litoquímica dos elementos maiores}

O conjunto de dados (Tabela 4) dos óxidos está representado no gráfico de elementos maiores em escala logarítmica (Figuras 6A e 6B). Também foi realizada a comparação da média dos óxidos de rochas ferríferas das áreas de estudo, com a média dos tipos Algoma, Lago Superior e Rapitan do Canadá.

Tabela 3. Sequência paragenética proposta para os minerais essenciais das rochas ferríferas das áreas de estudo.

\begin{tabular}{|c|c|c|}
\hline Mineralogia & Metamorfismo & Pós-metamorfismo* \\
\hline \multicolumn{3}{|l|}{ Formação ferrífera granular } \\
\hline Quartzo & --------------- & ------- \\
\hline Magnetita & ------- & \\
\hline Hematita & ------- & ------- \\
\hline Cummingtonita-grunerita & 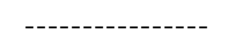 & \\
\hline Tremolita-actinolita & 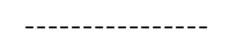 & \\
\hline Hidróxidos de ferro & & ---- \\
\hline \multicolumn{3}{|l|}{ Formação ferrífera bandada } \\
\hline Quartzo & 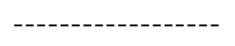 & ------ \\
\hline Magnetita 1 & --------- & \\
\hline Magnetita 2 & --------- & \\
\hline Hematita 1 & -------- & $--\cdot---$ \\
\hline Hematita 2 & --------- & ------ \\
\hline Cummingtonita-grunerita 1 & --------- & \\
\hline Cummingtonita-grunerita 2 & --------- & \\
\hline Tremolita-actinolita 1 & -------- & \\
\hline Tremolita-actinolita 2 & --------- & \\
\hline Hidróxidos de ferro & & 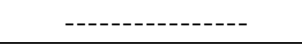 \\
\hline
\end{tabular}

*Os eventos de pós-metamorfismo podem incluir hidrotermalismo ou intemperismo. 


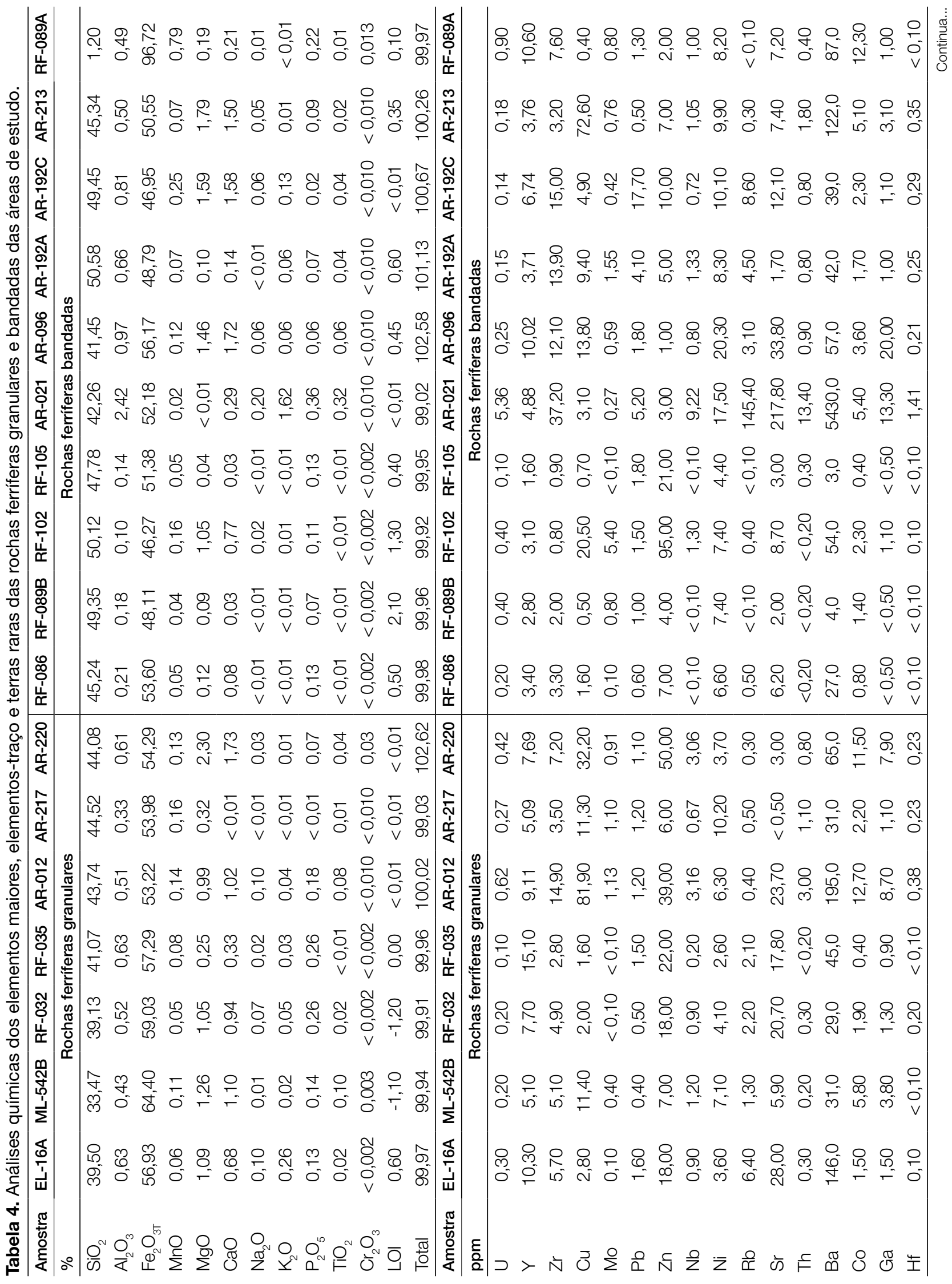




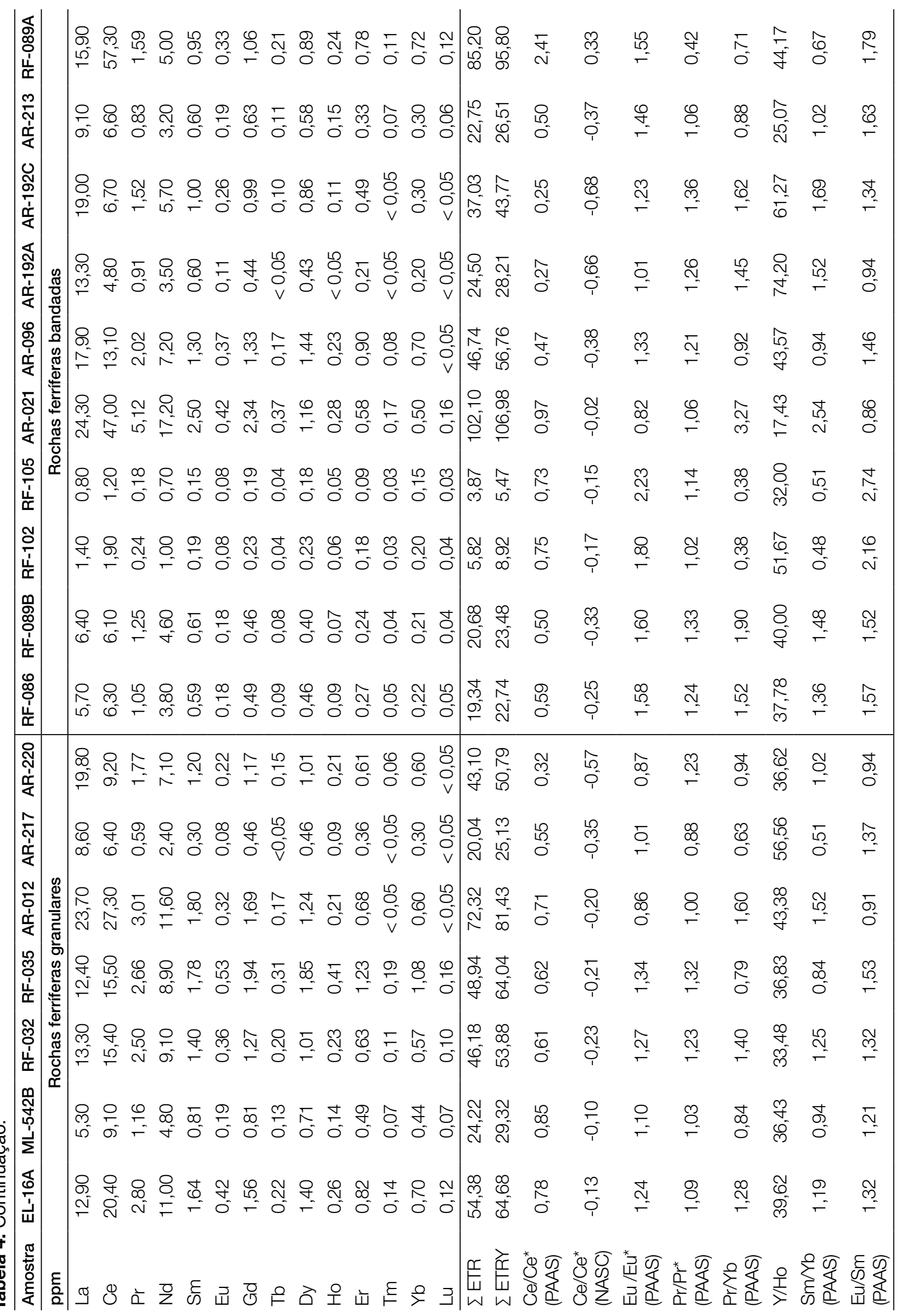


Na Figura 6, os dados seguem a tendência das formações ferríferas do Canadá, com a composição maior que $90 \%$ de $\mathrm{Fe}_{2} \mathrm{O}_{3 \mathrm{~T}}+\mathrm{SiO}_{2}$. Os elementos $\mathrm{Al}_{2} \mathrm{O}_{3}, \mathrm{MgO}$ e CaO ocorrem entre valores muito baixos até próximos de $3 \%$. Os óxidos $\mathrm{TiO}_{2}$, $\mathrm{MnO}, \mathrm{Na}_{2} \mathrm{O}, \mathrm{K}_{2} \mathrm{O}$ e $\mathrm{P}_{2} \mathrm{O}_{5}$ ocorrem com um percentual menor que $1 \%$. Somente a amostra AR-021 (Figura 6B) apresentou teor de $\mathrm{K}_{2} \mathrm{O}(1,6 \%)$ um pouco maior que os tipos genéticos do Canadá e a amostra RF-089A (Figura 6B), de minério de ferro maciço, tem baixo $\mathrm{SiO}_{2}$ e teor muito alto de $\mathrm{Fe}_{2} \mathrm{O}_{3 T}$.

Para ambos os grupos de rochas ferríferas (granulares e bandadas) das áreas de estudo, a distribuição dos óxidos encontra-se no limiar entre os tipos Algoma e Rapitan, principalmente nas formações ferríferas granulares. No geral, a litoquímica de elementos maiores para ocorrências de rochas ferríferas na Faixa Seridó é semelhante aos padrões dos tipos genéticos do Canadá. Porém, os teores de $\mathrm{SiO}_{2}$ são menores e o de $\mathrm{Fe}_{2} \mathrm{O}_{3 \mathrm{~T}}$ são um pouco maiores, mas a diferença ainda é pequena e desconsiderável. As somas desses dois óxidos são maiores que aqueles encontrados no Canadá. Os teores de $\mathrm{TiO}_{2}$ e $\mathrm{K}_{2} \mathrm{O}$ são muito próximos, com poucas exceções. $\mathrm{Al}_{2} \mathrm{O}_{3}, \mathrm{MgO}, \mathrm{CaO}, \mathrm{Na}_{2} \mathrm{O}, \mathrm{K}_{2} \mathrm{O}$ e $\mathrm{P}_{2} \mathrm{O}_{5}$ apresentam teores normalmente menores do que aqueles observados nas rochas

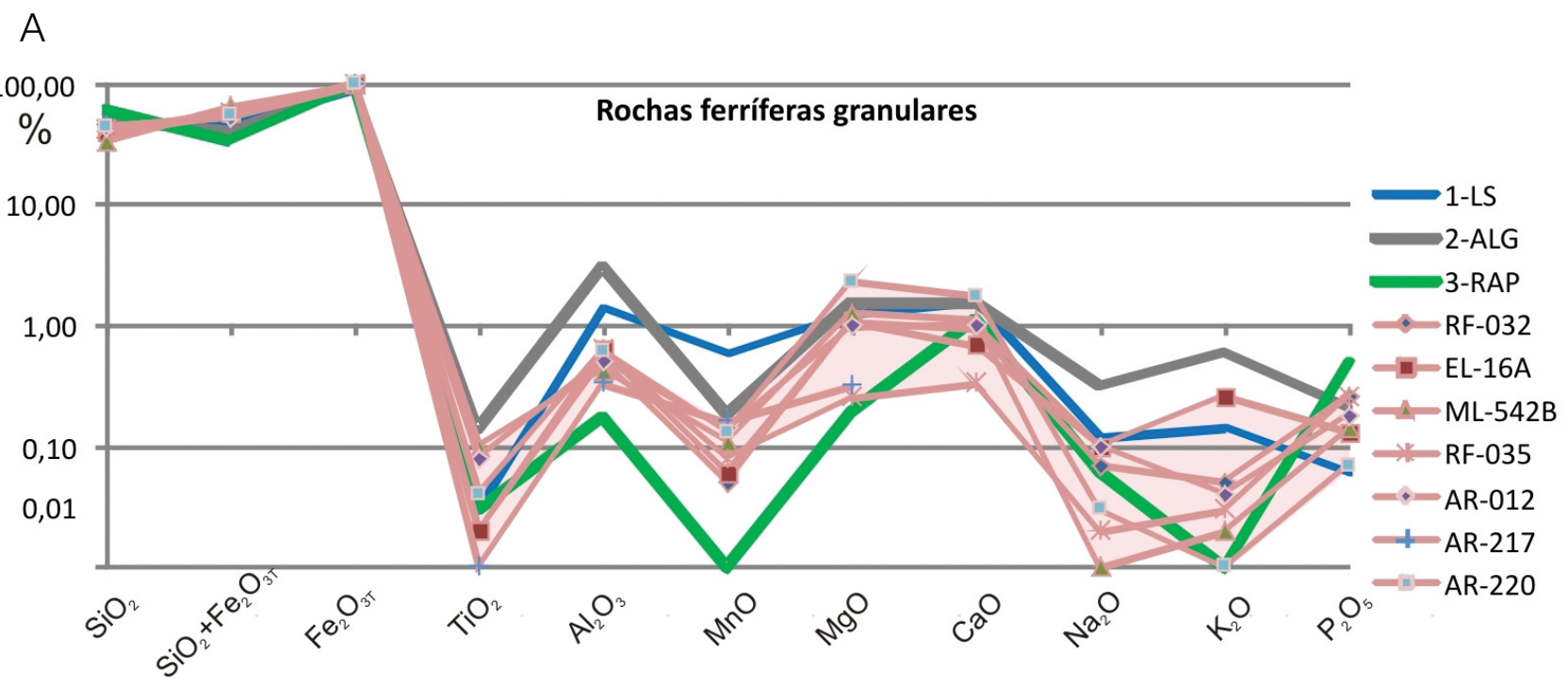

$\mathrm{B}$

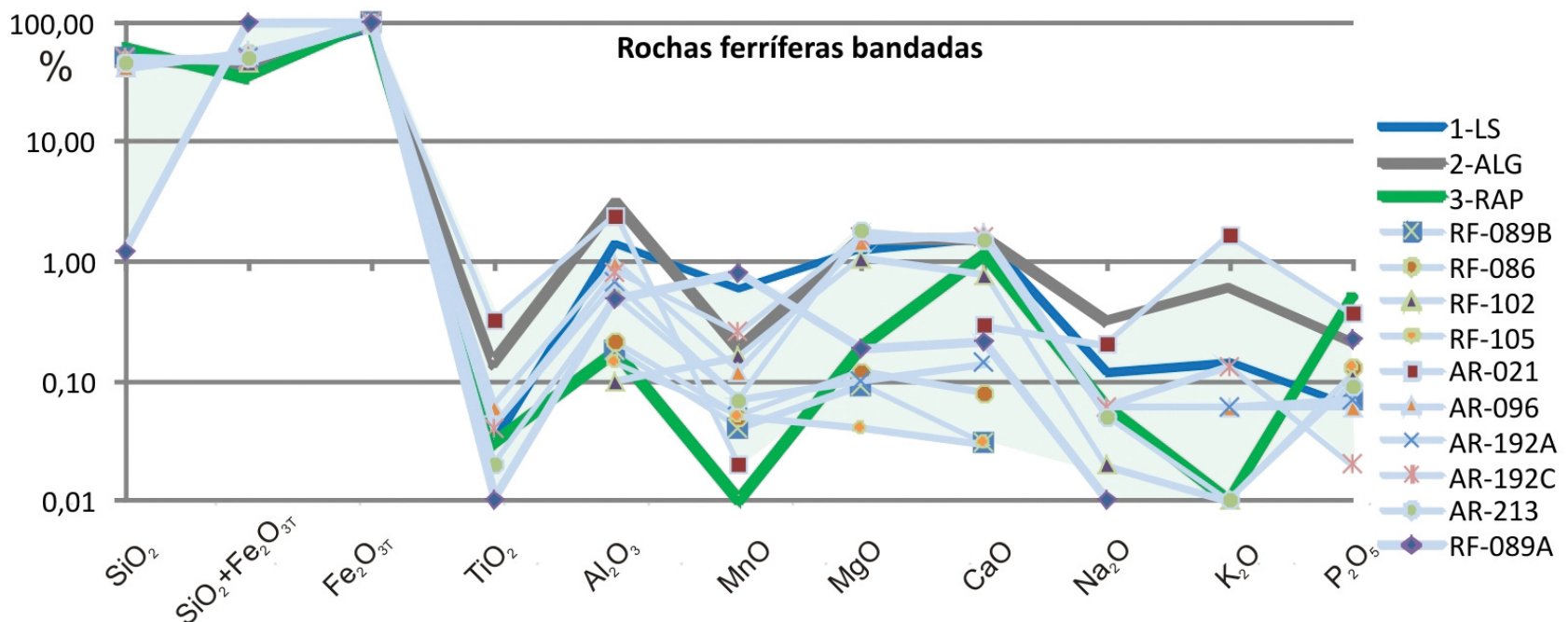

1-LS: Fácies óxido, tipo Lago Superior (Gross e McLeod, 1980); 2-ALG: Fácies óxido, tipo Algoma (Gross e McLeod, 1980); 3-RAP: formações ferríferas bandadas do Canadá, tipo Rapitan (Klein e Beukes, 1993).

Figura 6. Distribuição dos elementos químicos maiores das rochas ferríferas granulares (A) e bandadas (B) (linhas rosada e azul claro, respectivamente) locadas nas áreas de estudo, em comparação com as médias dos tipos Algoma, Lago Superior e Rapitan do Canadá (linhas cinza, azul e verde, respectivamente). Os polígonos em rosa e azul claro correspondem ao envelope com os resultados das análises químicas apresentadas neste trabalho. 
do Canadá. Apenas os teores de $\mathrm{MnO}$ são mais variados, ou para mais ou para menos da média dos tipos Algoma, Lago Superior e Rapitan.

Dentre as possíveis correlações entre os óxidos, apenas $\mathrm{SiO}_{2}$ versus $\mathrm{Fe}_{2} \mathrm{O}_{3 \mathrm{~T}}$ apresentou uma forte correlação, que no caso é negativa ou antitética $(R=-0,99)$ (Figura 7), resultado corroborado pela caracterização petrográfica dominante de apenas dois minerais nas rochas ferríferas da Faixa Seridó, representados por quartzo e minerais de ferro, principalmente óxidos.

\section{Litoquímica dos elementos-traço}

As rochas ferríferas das áreas de estudo mostram valores baixos de elementos-traço. Os valores médios são de aproximadamente 25 ppm e os máximos não ultrapassam 100 ppm, com exceção de $\mathrm{Rb}$, Sr e Ba, que extrapolam esse valor em algumas amostras. Dos elementos, 16 (V, Ag, As, Au, Bi, $\mathrm{Cd}, \mathrm{Hg}, \mathrm{Sb}, \mathrm{Tl}, \mathrm{Sc}, \mathrm{Se}, \mathrm{Sn}, \mathrm{Ta}, \mathrm{Be}, \mathrm{Cs}$ e W) ficaram abaixo dos limites de determinação ou mostram valores mensuráveis em tão poucas amostras que não estão representados na Tabela 4 e no gráfico multielementar (Figura 8); 6 (Mo, $\mathrm{Nb}, \mathrm{Rb}, \mathrm{Th}, \mathrm{Ga}$ e Hf) tiveram a maior parte das amostras mensuráveis, porém, algumas ficaram abaixo do limite de detecção; e 10 (U, Y, Zr, Cu, Pb, Zn, Ni, Sr, Ba e Co) foram detectados em todas as amostras.

Com os gráficos bivariantes de óxidos versus elementostraço não foi possível distinguir agrupamentos distintos de rochas ferríferas granulares e bandadas. Porém, outra maneira de analisar as concentrações de elementos-traço nas amostras de rochas ferríferas nas áreas de estudo é apresentando

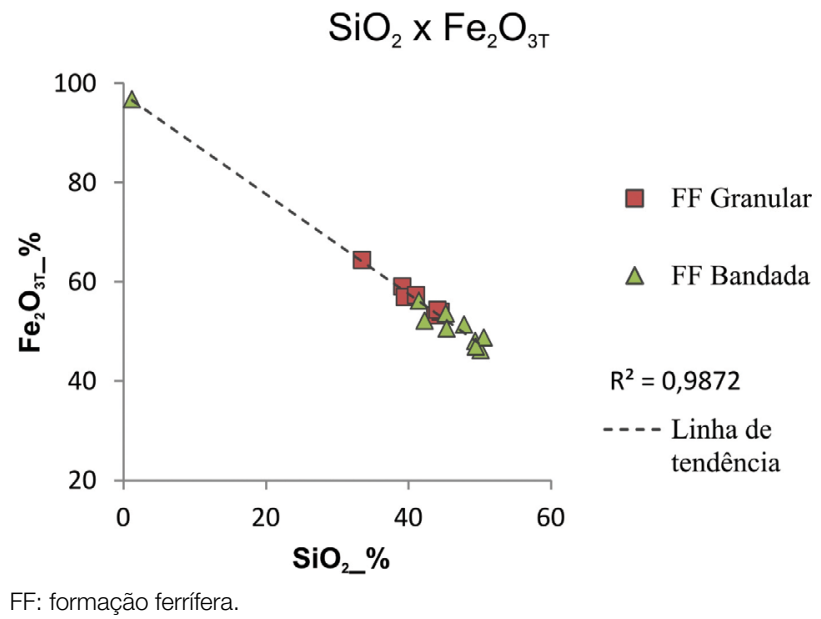

Figura 7. Correlação $\mathrm{SiO}_{2}$ versus $\mathrm{Fe}_{2} \mathrm{O}_{3 \mathrm{~T}}$ para o total de 17 amostras de ocorrências de rochas ferríferas granulares e bandadas na Faixa Seridó. A amostra na extremidade esquerda do gráfico é de minério de ferro maciço com mais de $67 \%$ de Fe. O valor de $\mathrm{R}^{2}$ corresponde ao coeficiente de determinação, que é muito próximo de 1 , indicando o ajustamento estatístico linear entre as amostras. os teores em ppm normalizados ao Pos-Archean Australian Shale (PAAS) (Figura 8), obtidos por McLennan (1989). Esse estudo é focado sobre a fonte do ferro e a análise da correlação dos elementos-traço com o reflexo da contribuição de fluidos hidrotermais e detríticos e sua relação com a mistura de sedimentos na água do mar (Gross, 1983; Bekker et al., 2010). As maiores concentrações de elementos-traço litófilos (Rb, Sr, Y, Zr) estão relacionadas ao grupo de formações ferríferas (FF) depositadas em sítios distais, enquanto que os elementos $\mathrm{V}, \mathrm{Co}$, Ni e $\mathrm{Cu}$ têm suas maiores concentrações relacionados ao grupo de $\mathrm{FF}$ depositadas em sítios proximais às fontes hidrotermais (Gross, 1983; Bekker et al., 2010).

Nos gráficos multielementares (Figura 8), percebem-se algumas particularidades entre os dois grupos de rochas $\mathrm{e}$ as concentrações de elementos-traço, permitindo uma separação entre eles. $O$ gráfico para as rochas ferríferas granulares é mais consistente (Figura 8A). São claras as anomalias positivas de $\mathrm{Zn}, \mathrm{Y}, \mathrm{Mo}$ e $\mathrm{Pb}$ e negativas bastante pronunciadas de $\mathrm{Rb}$ e $\mathrm{Zr}$, todas em relação ao PAAS. Para as rochas ferríferas bandadas existem dois conjuntos de amostras distintas (Figura 8B). As amostras RF-086, RF-089B, RF-102 e RF-105 apresentam as mesmas anomalias positivas e negativas das rochas ferríferas granulares, enquanto que as restantes apenas positivas de $\mathrm{Mo} \mathrm{e} \mathrm{Pb}$, evidenciando também um agrupamento característico que indica homogeneidade desse segundo conjunto de amostras. Porém, para ambos conjuntos de formações ferríferas bandadas, as curvas apresentam uma anomalia positiva discreta de $\mathrm{Ni}$ em relação ao PAAS, diferentemente das formações ferríferas granulares.

\section{Litoquímica dos elementos terras raras}

Os teores dos elementos terras raras (ETR) nas rochas ferríferas das áreas de estudo (polígonos nordeste e sudoeste) são baixos (teor máximo de $57 \mathrm{ppm}$ e médio de $3 \mathrm{ppm}$ ), corroborando aqueles observados nas BIFs fácies óxido no mundo (Appel, 1987; Davy, 1983). Appel (1987) diz que a distribuição dos ETR parece estar relacionada com o tipo de fácies, sendo o óxido o que apresenta os valores mais baixos. Dados de ETR em formação ferrífera bandada em Barbosa (2013) e Sial et al. (2015), também na região da Faixa Seridó, correspondem a formações ferríferas facies óxido com baixas concentrações de ETR.

Neste trabalho, a análise do comportamento dos ETR nas rochas ferríferas foi realizada normalizando os resultados pelo PAAS. A anomalia de $\mathrm{Eu}^{*}$ foi definida quantitativamente segundo a média geométrica recomendada por McLennan (1989) e a anomalia verdadeira de Ce*, enquanto que a anomalia de Pr* foi definida conforme as equações observadas em Planavsky et al. (2010).

O grau de enriquecimento de ETRL em relação ao ETRP é apresentado na razão normalizada ao PAAS de $\mathrm{Sm}$ e $\mathrm{Yb}$ : $(\mathrm{Sm} / \mathrm{Yb})_{\mathrm{N}}$. Os valores para as rochas ferríferas granulares 
variam de 0,51 até 1,52 , enquanto para as rochas ferríferas bandadas, de 0,48 até 1,69 , com exceção da amostra AR-021, com valor de 2,54. São dados similares aos dois grupos de rocha, que indicam tendências lineares (próximos de 1), exceto a amostra AR-021, que apresenta enriquecimento mais pronunciado de ETRL sobre ETRP.

As rochas ferríferas das áreas de estudo apresentam razão variada de Y/Ho entre 17 e 74.

\section{$\mathrm{Ce} / \mathrm{Ce} e^{\star}$}

Os valores resultantes de $\mathrm{Ce} / \mathrm{Ce}$ * normalizados pelo American Shale Composite Standard (NASC) de Haskin et al. (1968) e a fórmula apresentada em Wright et al. (1987) seguem na Tabela 4; e os dados estão melhor representados no gráfico $\mathrm{Ce} / \mathrm{Ce}^{*}$ versus $\mathrm{Nd}$ (Figura 9). Os valores de $\mathrm{Ce} / \mathrm{Ce}^{*}$, quando plotados contra $\mathrm{Nd}$, claramente situam-se abaixo de $-0,1$, indicando um ambiente oxidante, exceto para as amostras AR-021 e RF-089A, ambas de formação ferrífera bandada.

A abundância na concentração de La pode mascarar as anomalias de Ce. Para testar se as anomalias de $\mathrm{Ce} / \mathrm{Ce}$ * são reais, utilizou-se o diagrama discriminatório de Bau e Dulsky (1996), plotando Ce/Ce* versus $\operatorname{Pr} / \operatorname{Pr}$ * (Figura 10), ambos normalizados pelo folhelho (SN). Segundo Bau e Dulsky (1996), a combinação de $(\mathrm{Ce} / \mathrm{Ce} *)_{\mathrm{SN}}<1$ e $\left(\operatorname{Pr} / \mathrm{Pr}^{*}\right)_{\mathrm{SN}} \sim 1$ indicam anomalias positivas de La, conforme é possível

\section{A \\ Teores de elementos traços para rochas ferriferas granulares normalizadas pelo PAAS}

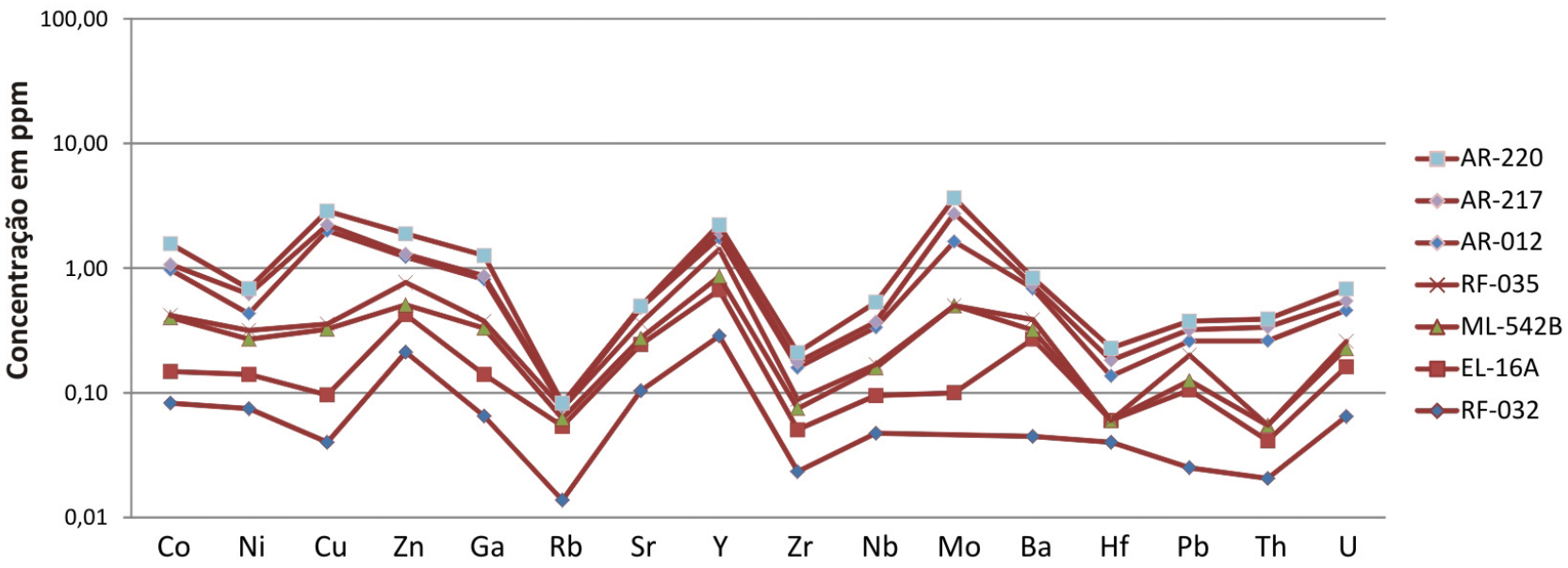

B

Teores de elementos traços para rochas ferriferas bandadas normalizados pelo PAAS

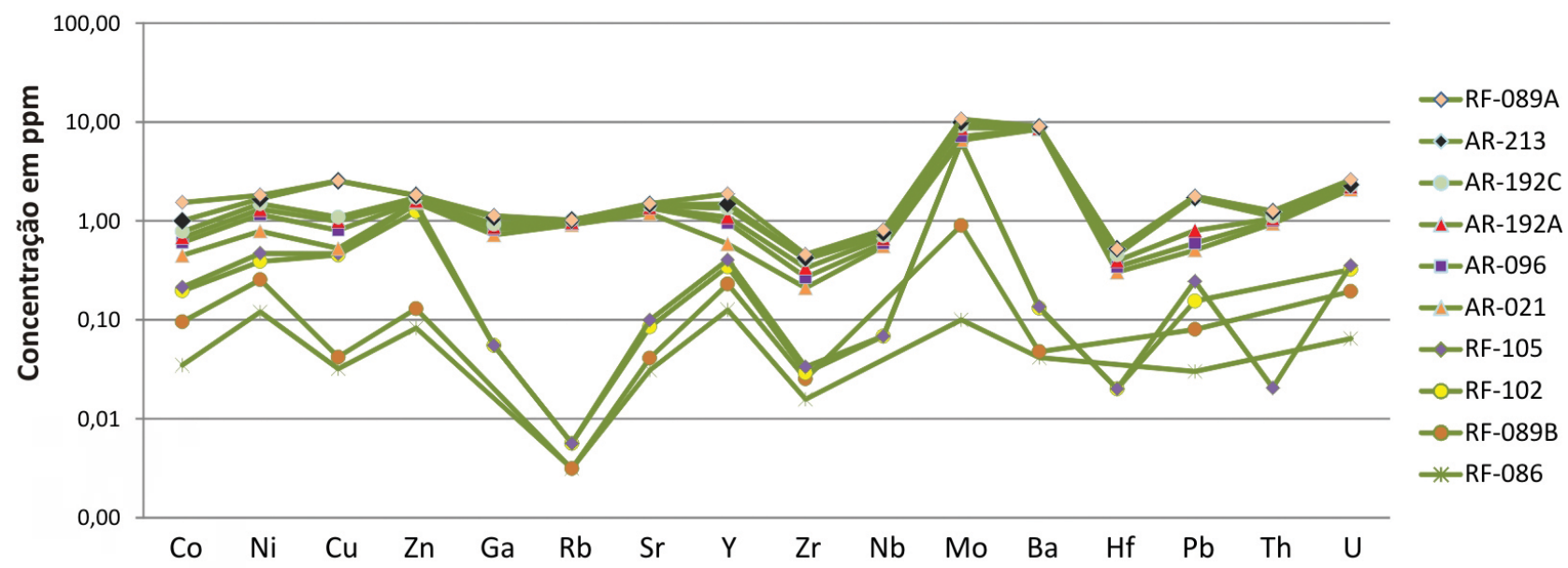

Figura 8. Gráfico multielementar da distribuição de teores de elementos-traço normalizados ao Post-Arquean Australian Shale (PAAS) para as formações ferríferas granulares (A) e bandadas (B) das áreas de estudo. Escala vertical mostra valores de concentração (ppm) em escala logarítmica. 
observar nas amostras que se encontram nos campos IIa e IV do gráfico CeN versus PrN (Figura 10). Apenas duas amostras encontram-se fora desses campos apresentados no gráfico da Figura 10: AR-021 e RF-089A. A amostra AR-021 encontra-se próxima ao campo I, enquanto a amostra RF-089A extrapola os limites do gráfico.

Conforme indicado na Figura 10, a maioria das amostras marca verdadeiras anomalias negativas em $\mathrm{Ce}$, sendo que algumas amostras registram tendências para anomalias positivas em La, mascarando as anomalias negativas de Ce. Isso implica que os grupos de rochas estudados, tanto as formações ferríferas granulares como as formações ferríferas bandadas, definem representantes extremos de condições da bacia, onde zonas de superposição evidenciam ambientes intermediários e/ou transicionais entre os sítios deposicionais, marcados pelo espalhamento das amostras no diagrama, em ambos os casos.

\section{$\mathrm{Eu} / \mathrm{Eu}^{*}$}

Segundo Klein (2005), diferenças na amplitude de anomalias de Eu resultam de um declínio da contribuição hidrotermal nas bacias oceânicas do Arqueano ao Neoproterozoico, mas Bau e Möller (1993) atribuem essa redução à queda de temperatura das soluções hidrotermais.

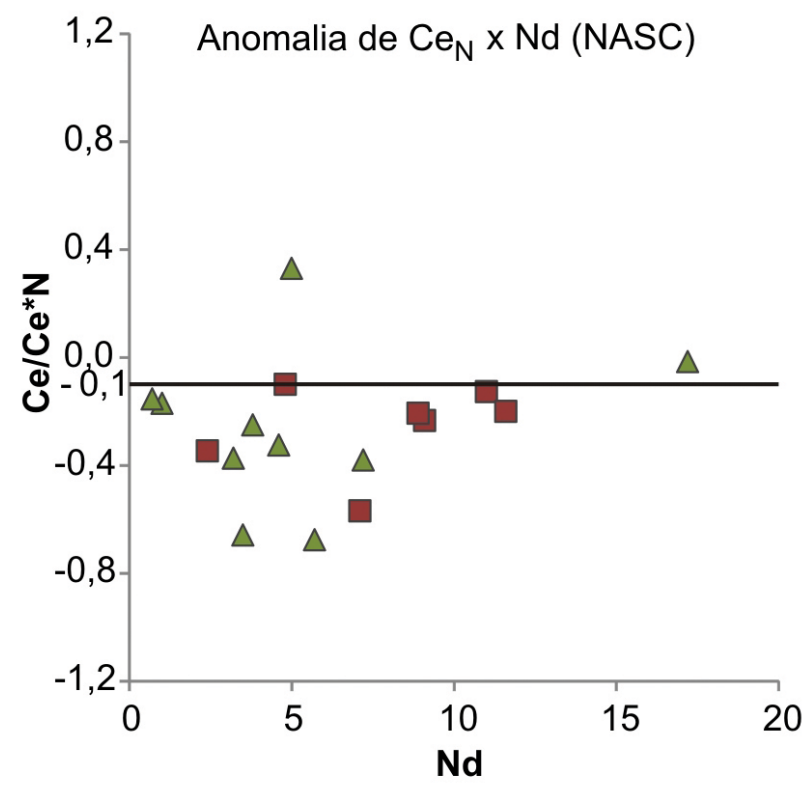

\section{Amostras de rochas ferríferas: \\ FF Granular $\quad \triangle F F$ Bandada}

FF: formação ferrífera.

Figura 9. Anomalia de $\mathrm{Ce} / \mathrm{Ce}^{\star}$ normalizado pelo North American Shale Composite (NASC) versus $\mathrm{Nd}$ das ocorrências de rochas ferríferas granulares e bandadas das áreas de estudo.
Nas áreas de estudo, quase todas as amostras normalizadas em relação ao PAAS mostram anomalias positivas de $\mathrm{Eu}\left(\mathrm{Eu} / \mathrm{Eu}^{*}>1\right.$, Tabela 4), típicas de soluções hidrotermais oceânicas originadas em sistemas convectivos submarinos. Em alguns locais, a incipiente ou ausente anomalia de Eu pode ser decorrente das condições de baixa temperatura do fluido mineralizador, nesse caso fluidos de alta temperatura são escassos ou ausentes. Apenas as amostras AR-012 e AR-220, de formação ferrífera granular, e AR-021, de formação ferrífera bandada, apresentam valores menores que 1 , porém bem próximas, representando assim uma suave anomalia negativa de $\mathrm{Eu}$.

\section{Gráficos de concentração de elementos terras raras}

Na Figura 11, observam-se os gráficos de padrão ETR normalizado ao PAAS em escala logarítmica, para as amostras de rochas ferríferas granulares (Figura 11A) e bandadas (Figura 11B), localizadas nas áreas de estudo.

As amostras de rochas ferríferas granulares (Figura 11A) apresentam anomalia negativa de $\mathrm{Ce}\left(\mathrm{Ce} / \mathrm{Ce}^{*}=0,32\right.$ a 0,85$)$ e anomalias positiva e negativa de európio $\left(\mathrm{Eu} / \mathrm{Eu}^{*}=0,86\right.$ a 1,34$)$ muito pouco pronunciadas. O comportamento dos ETR são aproximadamente planares, com leve fracionamento dos ETRP, mais pronunciado nas amostras AR-217, RF-035 e ML-542B.

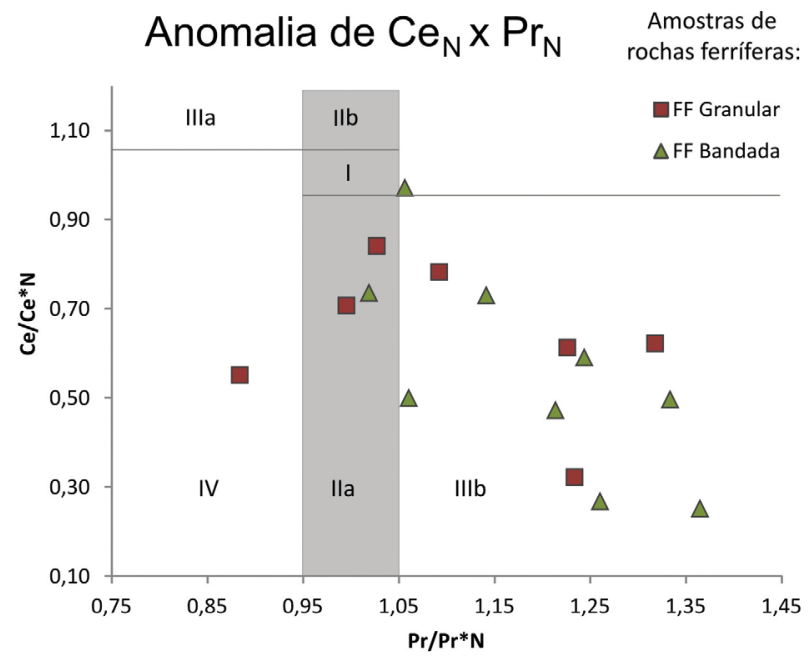

FF: formação ferrífera; I: sem anomalia; Ila: anomalia positiva de La causa aparente anomalia negativa de Ce; Ilb: anomalia negativa de La causa aparente anomalia positiva de Ce; Illa: real anomalia positiva de Ce; Illb: real anomalia negativa de Ce; IV: anomalia positiva de La disfarçada de anomalia positiva de Ce; FF: formações ferríferas.

Figura 10. Gráfico da anomalia de $\mathrm{Ce} / \mathrm{Ce}^{\star}$ versus $\mathrm{Pr} /$ $\mathrm{Pr}^{\star}$ normalizados pelo Post-Arquean Australian Shale (PAAS) (Bau e Dulski, 1996) para as formações ferríferas granulares e bandadas das áreas de estudo, na região central do Rio Grande do Norte. 
As amostras de rochas ferríferas bandadas (Figura 11B) apresentam anomalia negativa de $\mathrm{Ce}(0,25$ a 0,75$)$ pronunciada, exceto para as amostras AR- $021\left(\mathrm{Ce} / \mathrm{Ce}^{*}=0,97\right.$, anomalia negativa pouco pronunciada) e $\mathrm{RF}-089 \mathrm{~A}\left(\mathrm{Ce} / \mathrm{Ce}^{*}=\right.$ 2,41 , anomalia positiva). O európio apresenta-se com anomalias positivas $\left(\mathrm{Eu} / \mathrm{Eu}^{*}=1,01\right.$ a 2,23), exceto para amostra AR-021 $\left(\mathrm{Eu} / \mathrm{Eu}^{*}=0,82\right.$, anomalia negativa pouco pronunciada). O comportamento dos ETR é aproximadamente planar, com leve fracionamento dos ETRP, mais pronunciado nas amostras RF-102 e RF-105. Os ETRL apresentam fracionamento em relação aos ETRP na amostra AR-021, diferenciando do comportamento geral das amostras do grupo.

\section{Natureza e ambiente tectônico das formações ferriferas}

Alguns autores, como Johannesson et al. (2006) e Ilouga et al. (2013), discutem alterações na distribuição elementar de formações ferríferas aliadas a processos metamórficos e/ou intempéricos, algo comum, que ocorreu por exemplo na região da Faixa Seridó. É possível realizar análises gráficas com o uso dos elementos-traço $\mathrm{Zr}$ versus $\mathrm{Th}$, Ti versus $\mathrm{Zr}$ e Ti versus Th para observar o grau de pureza de formações ferríferas (Figura 12). Viehmann et al. (2016) estudaram a pureza química das formações ferríferas de Urucum, conseguindo discriminar as BIFs puras daquelas que são impuras e influenciadas por aporte de material sedimentar. Abrahão Filho (2016) estudou amostras das formações ferríferas bandadas de Senador Elói de Sousa, no Rio Grande do Norte, que se posicionaram em grande parte em campos de FF puras ou transicionais a sedimentos químico-exalativos dotados de alguma contribuição sedimentar.

As FF bandadas e granulares das áreas de estudo, na Faixa Seridó, posicionam-se principalmente no campo "pure BIF". Apenas algumas posicionaram-se fora desse campo, porém bem próximas, refletindo baixos níveis de impureza. Somente a amostra AR-021, nos gráficos de Th versus $\mathrm{Zr}$ e Th versus Ti, aproximou-se do campo "Detritus", evidenciando a influência da presença de material siliciclástico, como corroborado pela petrografia (maior quantidade de microclínio).

Para conhecimento do processo genético que sugere que sedimentos químicos ricos em metais hidrotermais podem ser distinguidos de depósitos hidrógenos formados por processos diagenéticos ou não hidrotermais, é possível analisar graficamente os elementos $\mathrm{Al}$, $\mathrm{Si}$, Fe e Mn baseados em suas abundâncias relativas (Bonatti, 1975; Adachi et al., 1986). Através do gráfico de $\mathrm{Al}_{2} \mathrm{O}_{3}$ versus $\mathrm{SiO}_{2}$ (Figura 13A), observa-se que as formações ferríferas granulares e bandadas das áreas de trabalho tiveram influência de fluidos hidrotermais, corroborando o diagrama ternário Al-Fe-Mn (Figura 13B), que apresenta o mesmo resultado, ou seja, as formações ferríferas estudadas configuram sedimentos químico-exalativos hidrotermais. A amostra RF-089A, de minério de ferro maciço, está no campo de depósitos hidrógenos no diagrama $\mathrm{Al}_{2} \mathrm{O}_{3}$ versus $\mathrm{SiO}_{2}$; porém, no diagrama ternário $\mathrm{Al}-\mathrm{Fe}-\mathrm{Mn}$, é confirmada como resultante da ação de fluidos hidrotermais.

Os ambientes tectônicos podem ser definidos através de gráficos com as razões $\mathrm{Al}_{2} \mathrm{O}_{3} /\left(100-\mathrm{SiO}_{2}\right)$ versus $\mathrm{Fe}_{2} \mathrm{O}_{3} /(100-$ $\mathrm{SiO}_{2}$ ) de Murray (1994) (Figura $14 \mathrm{~A}$ ) e $\mathrm{SiO}_{2}$ versus $\mathrm{Ka}_{2} \mathrm{O} /$ $\mathrm{Na}_{2} \mathrm{O}$ de Roser e Korsch (1986) (Figura 14B). As amostras de formações ferríferas granulares e bandadas nas áreas de estudo da Faixa Seridó estão plotadas em campos próximos a cadeias oceânicas (Figura 14A) localizadas nas imediações de margens continentais ativas transicionais a arcos de ilha (Figura 14B). Apenas a amostra AR-021 encontra-se no campo de margem passiva (Figura 14B).
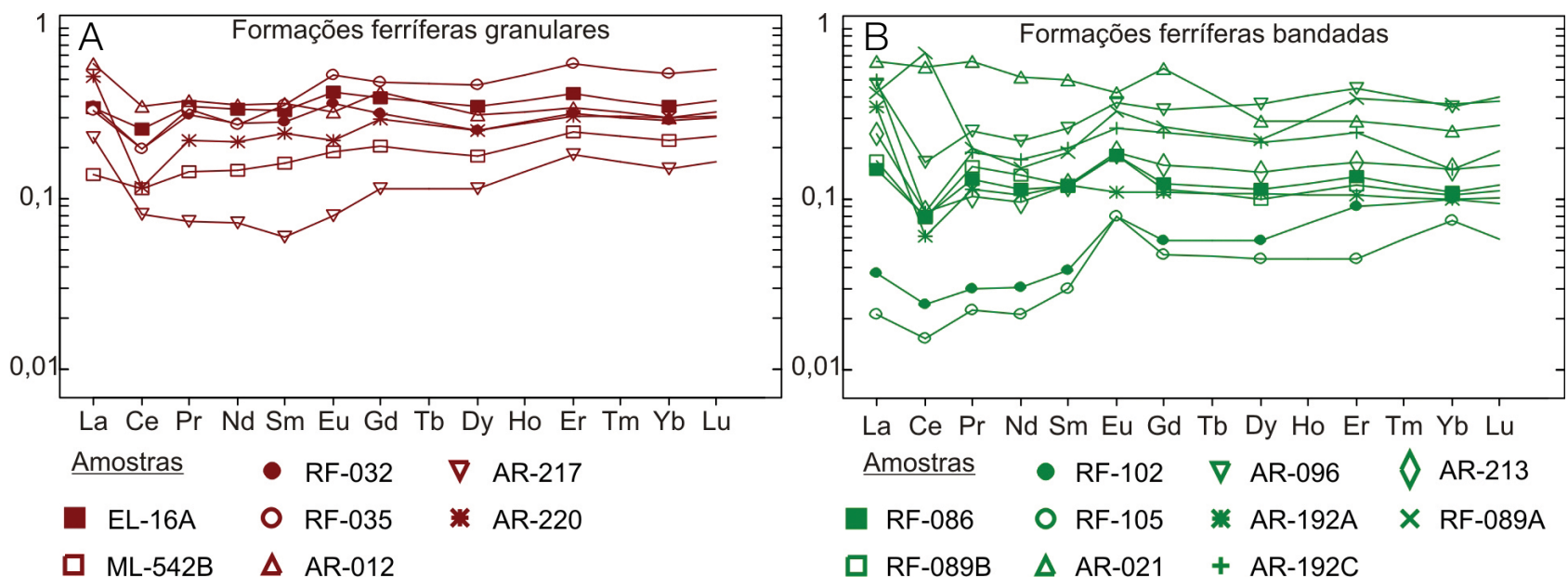

Figura 11. Padrão ETR normalizado ao Post-Arquean Australian Shale (PAAS) para as amostras de rochas ferríferas granulares (A) e bandadas (B) nas áreas de estudo. 


\section{DISCUSSÕES E CONCLUSÕES}

Através da petrografia realizada neste estudo, foram identificados dois grupos distintos, separados pelas suas características texturais (homogêneas ou granulares e bandadas). São rochas de origem metamórfica. Apresentam composição mineralógica simples, marcada pelo predomínio de quartzo, óxidos de ferro (magnetita e hematita) e anfibólios, que variam em percentual. Algumas formações ferríferas granulares e bandadas têm até $10 \%$ de anfibólios e outras apresentam de 15 a $30 \%$. As formações ferríferas são de fácies óxido, porém com componente silicato para os termos mais ricos em anfibólios. Os minerais opacos são magnetita e hematita, a qual ocorre em grande parte como produto de martitização, provavelmente originada durante a evolução do metamorfismo à medida que água foi liberada nas reações metamórficas. Os anfibólios identificados no MEV-EDS foram os cálcicos (actinolita, ferro-actinolita e ferro-edenita) e ferromagnesianos (grunerita) e a condição de cristalização conjunta desses dois grupos de minerais é
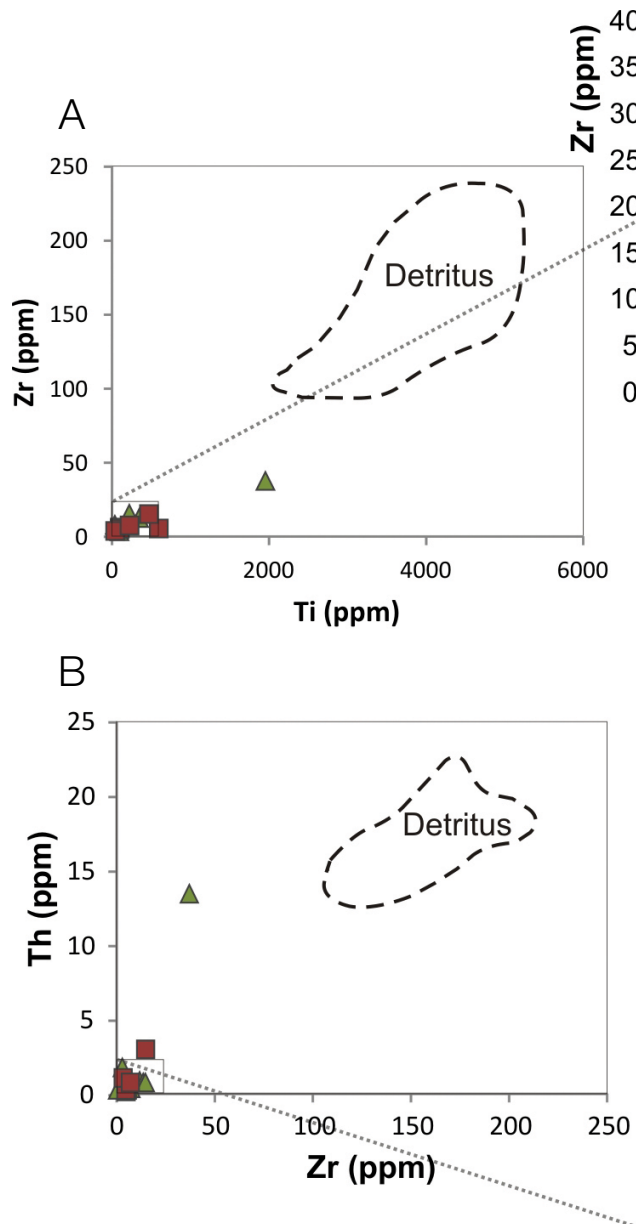

$\triangle$

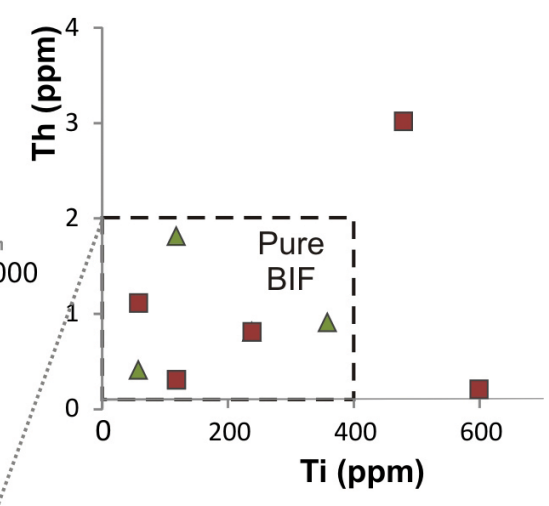

Rochas ferriferas: $\triangle F F$ Bandada 口FF Granular

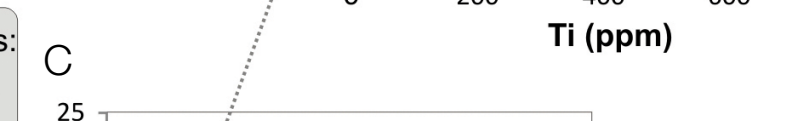

FF: formação ferrífera.
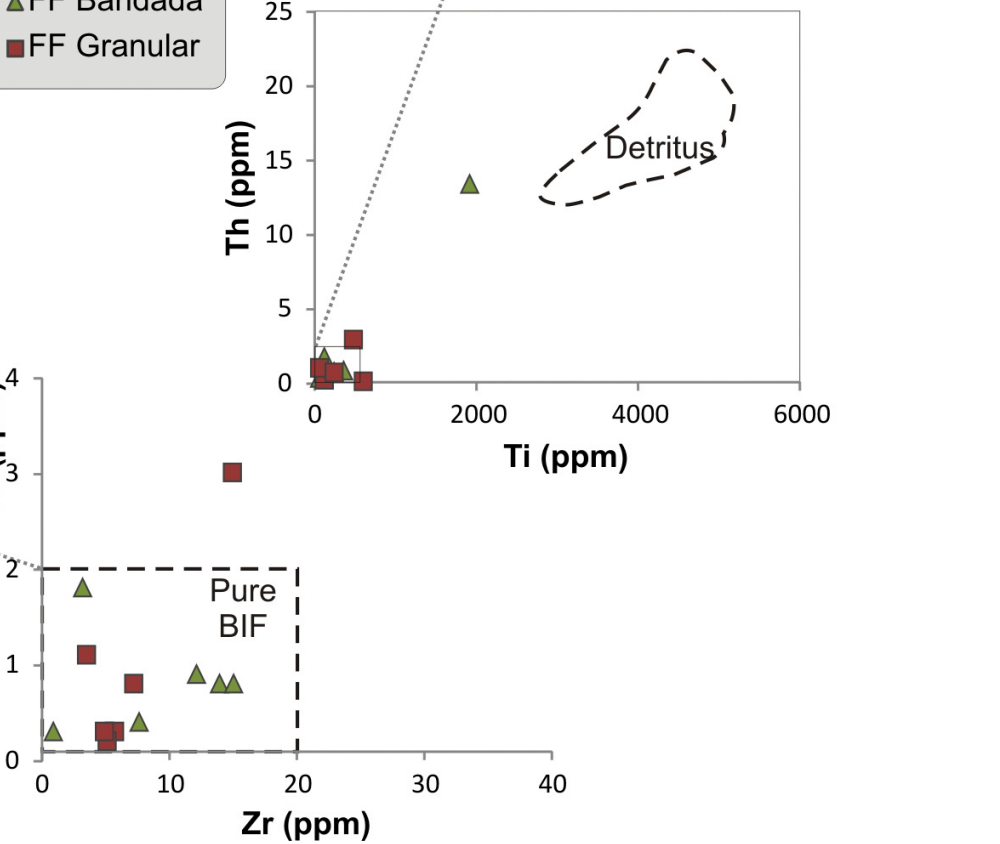

Figura 12. Diagramas binários utilizando elementos-traço para análise de pureza de formações ferríferas segundo Viehmann et al. (2016). (A) Ti versus Zr; (B) Zr versus Th; (C) Ti versus Th. Nesses gráficos, o campo "detritus" indica onde estão plotadas as amostras de sedimentos siliciclásticos finos. O campo "Pure BIF" reflete onde estão plotadas as amostras de BIFs puros. 
possível com a existência de componentes cálcicos durante a precipitação das rochas ferríferas.

As associações minerais observadas são comuns aos dois grupos de rochas estudados. O crescimento de cristais de quartzo ocorre associado a cristais de magnetita e anfibólios, mesmo quando o bandamento milimétrico típico da formação ferrífera bandada mostra a concentração de níveis mais ricos em quartzo, minerais opacos (magnetita e hematita) e anfibólios intercalados. As relações de inclusões minerais são variadas, pois esses três minerais (quartzo, opacos
A

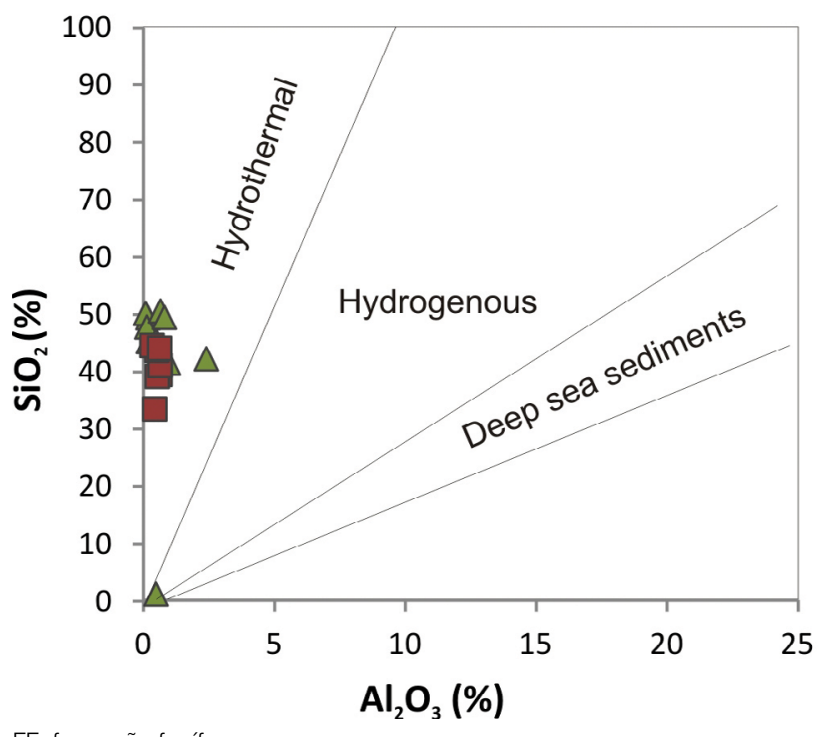

B

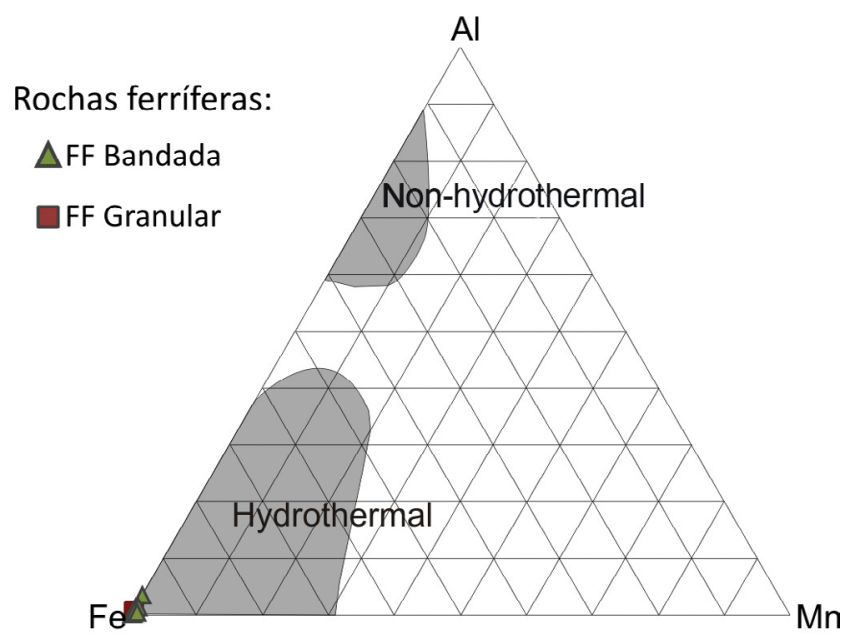

FF: formação ferrífera.

Figura 13. (A) Diagrama binário $\mathrm{Al}_{2} \mathrm{O}_{3}$ versus $\mathrm{SiO}_{2}$ de Bonatti (1975); (B) diagrama ternário Al-Fe-Mn de Adachi et al. (1986) mostrando o tipo de formação ferrífera em relação ao processo genético. Em ambos os casos as formações ferríferas granulares e bandadas estudadas na Faixa Seridó estão relacionadas a fluidos hidrotermais de água oceânica.
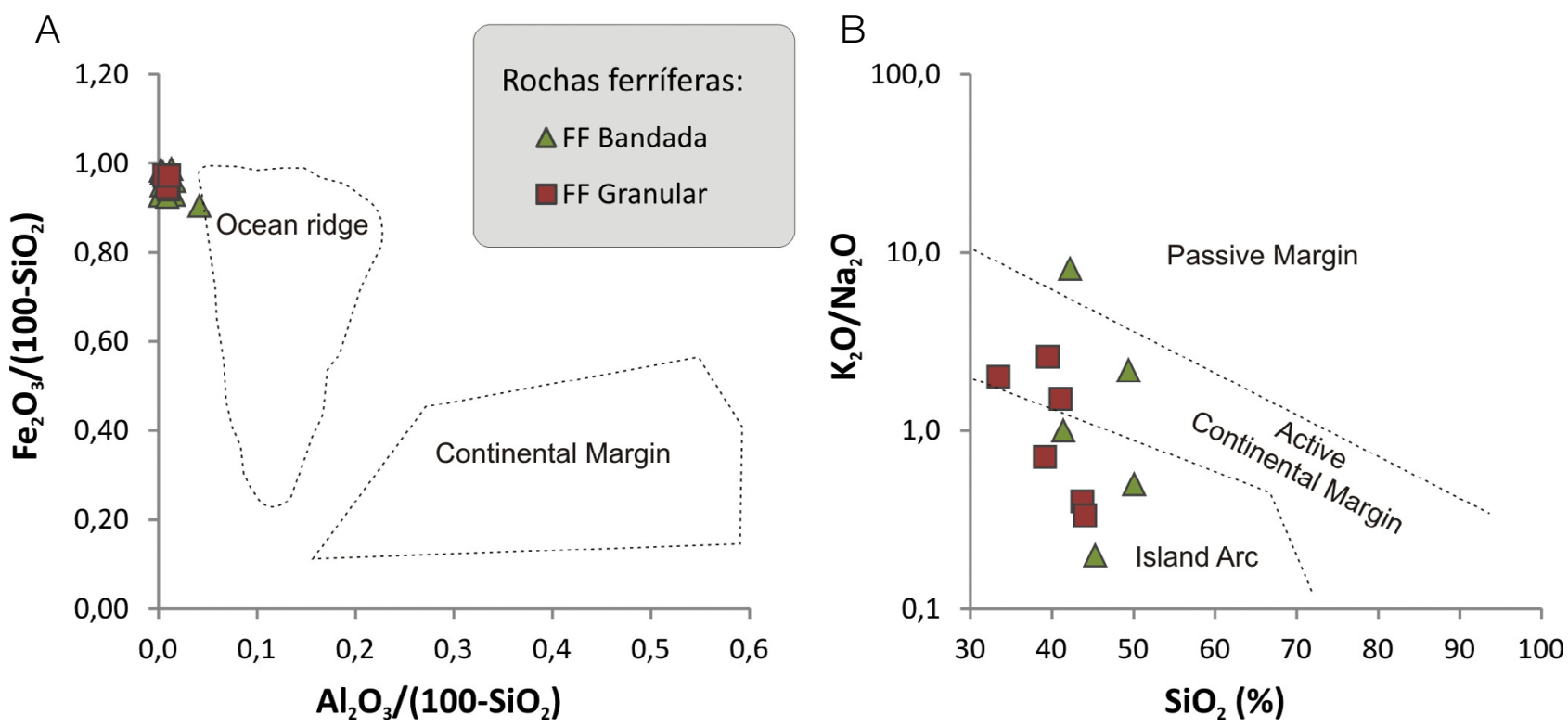

FF: formação ferrífera.

Figura 14. (A) Diagrama $\mathrm{Al}_{2} \mathrm{O}_{3} /\left(100-\mathrm{SiO}_{2}\right)$ versus $\mathrm{Fe}_{2} \mathrm{O}_{3} /\left(100-\mathrm{SiO}_{2}\right)$ (Murray, 1994) com as amostras de formações ferríferas granulares e bandadas da Faixa Seridó próximas ao campo de cadeias oceânicas; (B) diagrama $\mathrm{SiO}_{2}$ versus $\mathrm{Ka}_{2} \mathrm{O} / \mathrm{Na}_{2} \mathrm{O}$ (Roser e Korsch, 1986) com as amostras de formações ferríferas granulares e bandadas da Faixa Seridó, principalmente entre os campos de margens continentais ativas a arcos de ilha. 
e anfibólios) ocorrem como inclusões uns nos outros, indicando o crescimento de diferentes gerações durante o metamorfismo. No geral, todo o conjunto observado é de associações minerais de grau metamórfico médio (xisto verde e anfibólito), com temperaturas que variam de 450 até $550^{\circ} \mathrm{C}$ e pressões que variam de 2 até 5 kbar.

Quanto à litoquímica das rochas ferríferas das áreas de estudo, a análise dos elementos maiores permitiu identificar que as rochas ferríferas granulares e bandadas assemelhamse aos tipos Algoma e Rapitan do Canadá. $\mathrm{SiO}_{2}$ e o $\mathrm{Fe}_{2} \mathrm{O}_{3 \mathrm{~T}}$ somam mais de $90 \%$ das amostras e apresentam uma correlação negativa ou antitética, resultado de uma caracterização petrográfica dominante de dois minerais, representados por quartzo e minerais de ferro, principalmente óxidos e hidróxidos de ferro.

O gráfico de concentração de elementos-traço normalizados pelo PAAS indica claramente o agrupamento de rochas com as amostras de formações ferríferas granulares apresentando um comportamento mais regular, com as mesmas anomalias positivas e negativas em relação ao PAAS. Porém, as amostras de rochas ferríferas bandadas se apresentam em dois conjuntos distintos. Um grupo com as mesmas anomalias positivas e negativas das rochas ferríferas granulares; o outro com apenas positivas de Mo e $\mathrm{Pb}$. Porém, todas as amostras de FF bandadas apresentam uma anomalia positiva discreta de Ni em relação ao PAAS, distinguindo-se das amostras de formações ferríferas granulares. Provavelmente as FF bandadas foram geradas por lixiviação submarina de rochas máficas ou ultramáficas, já sugerido por Sial et al. (2015).

Os teores dos ETR são baixos (teor máximo de $57 \mathrm{ppm}$ e médio de $3 \mathrm{ppm}$ ), corroborando aqueles observados nas FF fácies óxido de todo o mundo. Nas rochas ferríferas bandadas, a concentração dos ETR é mais variada, pois as curvas de cada amostra apresentam comportamentos mais diversificados, corroborado a variação mineralógica perante a variação percentual de anfibólios. As anomalias negativas de Ce e positivas de Eu são normalmente pronunciadas. Ocorre leve fracionamento dos ETRP, mas o comportamento é bem linear, sem fracionamento. Apenas a amostra AR-021 tem comportamento distinto de todo o grupo; porém, é uma amostra com uma quantidade significativa de microclínio e leve alteração para argilominerais, de uma FF com forte componente siliciclástico, ou seja, com maior aporte de terrígenos. O padrão de terras raras das rochas ferríferas granulares é mais consistente, indicando que as rochas são mais similares quimicamente. As concentrações de ETR são mais parecidas. As rochas apresentam anomalia negativa de $\mathrm{Ce}$ e positiva e negativa de $\mathrm{Eu}$, mas pouco pronunciadas (próximo de 1). O fracionamento dos ETRP é mais discreto, embora seja mais consistente (curvas mais similares) que nas FF bandadas.
A razão Y/Ho típica da água do mar fica entre $60 \mathrm{e}$ 90 , enquanto os valores para águas continentais se situam mais próximos dos valores crustais (26 a 27) (Planavsky et al., 2010). Levando isso em consideração, quase todas as amostras apresentam alguma influência de águas continentais. Apenas as amostras RF-102, AR-217, AR-192A e AR-192C (ambas do mesmo afloramento) apresentam mais influência de águas marinhas. A amostra AR-217 é de rocha ferrífera granular, enquanto as outras três são de rochas ferríferas bandadas.

As anomalias de Ce são dominantemente anomalias negativas verdadeiras, típicas de ambiente oxidante, exceto para as amostras AR-021 e RF-089A, ambas de FF bandada. Essas duas amostras apresentam composição mineralógica (AR-021 com 20\% de microclínio) e química (RF-089A > $67 \%$ de $\mathrm{Fe}$ ) diferente das demais $\mathrm{FF}$ estudadas, condição que por si só poderia causar desvio no conteúdo de Ce. As amostras AR-012 e AR-102, de FF bandada e ML-542B, de FF granular, apresentam anomalias positivas de La, que mascaram as anomalias negativas de Ce. Todas as outras amostras que estão dispersas no campo de anomalias negativas verdadeiras de Ce estão amplamente dispersas, indicando representantes diversos de condições de oxidação da bacia e evidenciando ambientes transicionais entre os sítios deposicionais; porém, em bacias distintas e períodos geológicos diferentes.

As anomalias positivas de Eu indicam que a maior parte das amostras de FF bandada estão mais próximas de chaminés hidrotermais oceânicas. Enquanto as amostras de FF granulares estão em porções mais distais. Nesse caso, as anomalias são negativas $(<1)$ ou positivas (próximas de 1 ).

Quanto à natureza da formação das rochas ferríferas, os gráficos binários com as relações entre $\mathrm{Th}, \mathrm{Zr}$ e Ti em ppm permitiram identificar que os grupos de FF granulares e bandadas estudados neste trabalho são rochas puras quimicamente, com poucos níveis de impurezas - exceto a amostra AR-021, que teve presença de material siliciclástico durante a sua deposição. Já diagramas binários de $\mathrm{SiO}_{2}$ e $\mathrm{Al}_{2} \mathrm{O}_{3}$ em \% de peso e ternários de Al-Fe-Mn indicam que a totalidade das amostras de formações ferríferas bandadas e granulares foi formada a partir da água do mar, com importante contribuição da ação de fluidos hidrotermais submarinos, ou seja, configuram sedimentos químico-exalativos hidrotermais.

Os diagramas específicos para identificação dos ambientes tectônicos para formação das rochas ferríferas granulares e bandadas estudadas na Faixa Seridó indicam principalmente cadeias oceânicas localizadas nas imediações de margens continentais ativas transicionais a arcos de ilha. São condições parecidas com os modelos discutidos por Abrahão Filho (2016) para FF bandadas no Arqueano e FF bandadas por Sial et al. (2015) no Neoproterozoico. 


\section{Bacia de sedimentação de rochas ferríferas}

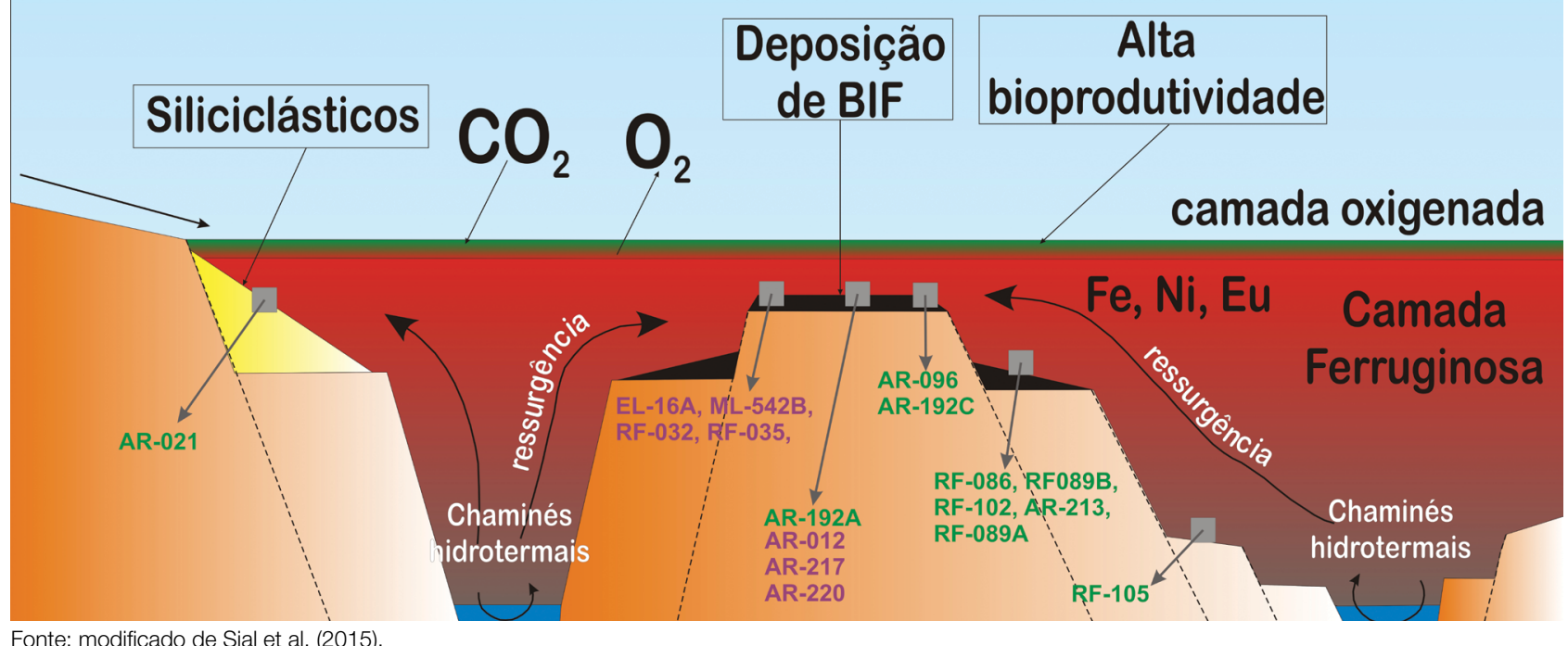

Fonte: modificado de Sial et al. (2015).

Figura 15. Modelo deposicional esquemático para as formações ferríferas granulares e bandadas das áreas de estudo na Faixa Seridó. O quadrado cinza claro representa a amostra coletada. Em verde estão identificadas as amostras de formações ferríferas bandadas e em roxo as formações ferríferas granulares.

As FF granulares encaixadas nas rochas do Complexo Caicó são provavelmente paleoproterozoicas, enquanto as FF bandadas estão encaixadas nas rochas da Formação Jucurutu, de idade neoproterozoica. No primeiro caso, sugere-se que as FF granulares estão repousando sobre sequências de rochas metassedimentares correlatas ao Complexo Caicó. Mesmo ocorrendo provavelmente em períodos distintos, os dados observados sugerem que todo esse conjunto de amostras de rochas ferríferas granulares e bandadas foi depositado em condições similares, portanto, no mesmo contexto tectônico, de pequenas bacias marinhas rasas, em estágio avançado de fechamento, com forte influência de chaminés hidrotermais, como proposto por Sial et al. (2015) e Abrahão Filho (2016). No caso das FF bandadas, a presença de terrígenos em maior ou menor proporção (variação mineralógica mais pronunciada de anfibólios) e presença de Ni indica a lixiviação de rochas máficas ou ultramáficas em sistemas hidrotermais como observado pela presença de $\mathrm{Cr}$, como já sugerido por Sial et al. (2015).

Por fim, o modelo proposto (Figura 15) com a distribuição das FF para as amostras estudadas indicam provavelmente períodos distintos, mas em condições similares. Portanto, considerando-se todos os dados analisados, e com base no modelo deposicional proposto por Sial et al. (2015), sugerese que a distribuição espacial para as amostras de FF granulares (correlacionadas às rochas do Complexo Caicó) e para as amostras de $\mathrm{FF}$ bandadas (correlacionadas às rochas da Formação Jucurutu), das áreas de estudo, ocorreu em períodos geológicos distintos, mas os processos e ambientes de formação para cada amostra são análogos.

\section{REFERÊNCIAS}

Abrahão Filho, E. A. (2016). A gênese das formações ferriferas e das rochas máficas associadas às rochas piroxeníticas da porção central do Maciço São José do Campestre, Rio Grande do Norte, Brasil. Dissertação (Mestrado). Brasilia: Instituto de Geociências - UnB.

Adachi, M., Yamamoto, K., Sugisaki, R. (1986). Hydrothermal chert and associated cherts from the Northern Pacific, their geological significance as indication of ocean ridge activity. Sedimentary Geology, 47, 125-148.

Angelim, L. A. A., Nesi, J. R., Torres, H. H. F., Medeiros, V. C., Santos, C. A., Veiga Junior, J. P., Mendes, V. A. (2006). Geologia e recursos minerais do Estado do Rio Grande do Norte: Texto explicativo dos mapas geológico e de recursos minerais do Estado do Rio Grande do Norte Escala 1:500.000. Recife: Serviço Geológico Brasileiro (CPRM).

Appel, P. W. U. (1987). Geochemistry of the Early Archean Isua Iron Formation, West Greenland. In: P. W. U. Appel, G. L. LaBerge (Eds.). Precambrian Iron-Formations, 31-69. Athens: Theophrastus Publications.

Barbosa, I. G. (2013). Mina do Bonito: tipologia e geoquimica dos minérios de ferro - Jucurutu/RN - Brasil. Dissertação (Mestrado). Fortaleza: Programa de Pós-Graduação em Geologia - UFC. 
Bau, M., Dulski, P. (1996). Distribution of yttrium and rareearth elements in the Penge and Kuruman iron-formations, Transvaal Supergroup, South Africa. Precambrian Research, 79(1-2), 37-55.

Bau, M., Möller, P. (1993). Rare earth element systematics of the chemically precipitated component in Early Precambrian iron-formations and the evolution of the terrestrial atmosphere-hydrosphere-lithosphere system. Geochimica et Cosmochimica Acta, 57 (10), 2239-2249.

Bekker, A., Slack, J. F., Planavsky, N., Krapez, B., Hofmann, A., Konhauser, K. O., Rouxel, O. J. (2010). Iron formation: The sedimentary product of a complex interplay among mantle, tectonic, oceanic, and biospheric processes. Economic Geology, 105, 467-508.

Bonatti, E. (1975). Metallogenesis at oceanic spreading centres. Annual Review of Earth and Planetary Sciences, 3, 401-433.

Brito Neves, B. B., Santos, E. J., Van Schmus, W. R. (2000). Tectonic History of the Borborema Province, Northeast Brazil. In: U. G. Cordani, E. J. Milani, A. Thomaz Filho, D. A. Campos (Eds.). Tectonic Evolution of South America, 151182. Rio de Janeiro: 31st International Geological Congress.

Campelo, R. C. (1999). Análise de terrenos na porção setentrional da Província Borborema, NE do Brasil: Integração de dados geológicos e gravimétricos. Dissertação (Mestrado). Natal: Programa de Pós-Graduação em Geodinâmica e Geofísica - UFRN.

Campos, M. S. (2011). Quimioestratigrafia isotópica de carbono e estrôncio e geoquímica de elementos terras raras em formações carbonáticas e ferríferas do cinturão Seridó, Nordeste do Brasil. Dissertação (Mestrado). Recife: Programa de Pós-Graduação em Geociências - UFPE.

Cavalcante, R., Cunha, A. L. C., Medeiros, V. C. (2015). Programa Geologia do Brasil-PGB. Projeto Provincias Metalogenéticas do Brasil: Area PB - RN (Borborema Leste). Estados do Rio Grande do Norte e Paraíba. 1 mapa colorido, $90 \times 115 \mathrm{~cm}$. Escala 1:250.000.

Costa, A. P., Dantas, A. R. (2014). Programa Geologia do Brasil-PGB. Lajes. Folha SB.24-X-D-VI. Estado do Rio Grande do Norte. Carta Geológica. Recife: CPRM. 1 mapa colorido, $90 \times 70 \mathrm{~cm}$. Escala 1:100.000.

Dantas, A. R., Costa, A. P. (2014). Programa Geologia do Brasil-PGB. Lajes. Folha SB.24-X-D-VI. Estado do Rio Grande do Norte. Carta de Recursos Minerais. Recife: CPRM. 1 mapa colorido, $91 \times 67 \mathrm{~cm}$. Escala 1:100.000.
Dantas, E. P., Cruz, R. F., Nascimento, M. A. L., Dantas, A. R. (2012). Programa Geologia do Brasil - PBG. Currais Novos. Folha SB.24-Z-B-II. Estados do Rio Grande do Norte e Paraiba. Carta de Recursos Minerais. Recife: CPRM. 1 mapa colorido, $91,06 \times 59,30 \mathrm{~cm}$. Escala 1:100.000.

Davy, R. (1983). A contribution on the chemical composition of Precambrian Iron-Formations. In: A. F. Trendall, R. C. Morris (Eds.). Iron Formation Facts and Problems, 325343. Amsterdam: Elsevier.

Dedavid, B. A., Gomes, C. I., Machado, G. (2007). Microscopia eletrônica de varredura: aplicações e preparação de amostras: materiais poliméricos, metálicos e semicondutores. Porto Alegre: EDIPUCRS.

Ferreira, A. C. D., Dantas, E. L., Souza, V. S. (2015). Litogeoquímica das formações ferríferas bandadas da região de Lajes-RN, Terreno Rio Piranhas, Domínio Rio Grande do Norte, NE do Brasil. XV Congresso Brasileiro de Geoquímica, resumos expandidos. Brasília: SBGq.

Figueiredo, B. S. (2012). Geoquimica e gênese das formações ferriferas e metacarbonatos da porção sul do Maciço São José do Campestre, Província Borborema. Dissertação (Mestrado). Brasília: Instituto de Geociências - UnB.

Gross, G. A. (1983). Tectonic systems and the deposition of iron-formation. Precambrian Research, 20, 171-187.

Gross, G. A., McLeod, C. R. (1980). A preliminary assessment of the chemical composition of iron formation in Canada. Canadian Mineralogist, 18, 223-229.

Haase, C. S. (1982a). Metamorphic petrology of the Negaunee Iron Formation, Marquette district, northern Michigan: Mineralogy, metamorphic reactions and phase equilibria. Economic Geology, 77, 60-81.

Haase, C. S. (1982b). Phase equilibria in metamorphosed iron-formations: qualitative T-X $(\mathrm{CO} 2)$ petrogenetic grids. American Journal of Science, 282, 1623-1654.

Haskin, L. A., Haskin, M. A., Frei, F. A., Wildman, T. R. (1968). Relative and absolute terrestrial abundances of the rare earths. In: L. H. Ahrens (Ed.). Origin and distribution of the elements, v. 1, 889-911. Oxford: Pergamon.

Hollanda, M. H. B. M., Archanjo, C. J., Bautista, J. R., Souza, L. C. (2015). Detrital zircon ages and Nd isotope compositions of the Seridó and Lavras da Mangabeira basins (Borborema Province, NE Brazil): Evidence for exhumation and recycling associated with a major shift in sedimentary provenance. Precambrian Research, 258, 186-207. 
Hollanda, M. H. B. M., Archanjo, C. J., Souza, L. C., Dunyi, L., Armstrong, R. (2011). Long-lived Paleoproterozoic granitic magmatism in the Seridó-Jaguaribe domain, Borborema Province-NE Brazil. Journal of South American Earth Sciences, 32, 287-300.

Ilouga, D. C. I, Suh, C. E., Tanwi, G. R. (2013). Textures and Rare Earth Elements Composition of Banded Iron Formations (BIF) at Njweng Prospect, Mbalam Iron Ore District, Southern Cameroon. International Journal of Science Research, 4, 146-165.

James, H. L. (1954). Sedimentary facies of iron-formation. Economic Geology, 49, 235-293.

James, H. L. (1955). Zones of regional metamorphism in the Precambrian of northern Michigan. Bulletion of the Geological Society of America, 66, 1455-1488.

Jardim de Sá, E. F. (1994). A Faixa Seridó (Província Borborema, NE Brasil) e o seu significado geodinâmico na cadeia Brasiliana/Pan-Africana. Tese (Doutorado). Brasília: Instituto de Geociências - UnB.

Jardim de Sá, E. F., Salim, J. (1980). Reavaliação dos conceitos estratigráficos na região do Seridó (RN-PB). Mineração e Metalurgia, 80(417), 16-28.

Johannesson, K. H., Hawkins, D. L., Cortés, A. (2006). Do Archean chemical sediments record ancient seawater rare earth element patterns? Geochimica et Cosmochimica Acta, 70, 871-890.

Klein, C. (1973). Changes in mineral assemblages with metamorphism of some banded iron-formations. Economic Geology, 68, 1075-1088.

Klein, C. (1983). Diagenesis and metamorphism of Precambrian iron-formations. In: A. F. Trendall, R. C. Morris (Eds.). Iron-Formation: Facts and Problems, 417469. Amsterdam: Elsevier.

Klein, C. (2005). Some Precambrian banded iron-formations (BIFs) from around the world: Their age, geologic setting, mineralogy, metamorphism, geochemistry, and origin. American Mineralogist, 90, 1473-1499.

Klein, C., Beukes, N. (1993). Sedimentology and Geochemistry of the Glaciogenic Late Proterozoic Rapitan Iron-Formation in Canada. Economic Geology, 88, 542-565.

Leake, B. E., Woolley, A. R., Arps, C. E. S., Birch, W. D., Gilbert, M. C., Grice, J. D., Hawthorne, F. C., Kato, A., Kisch, H. J.,
Krivovichev, V. G., Linthout, K., Laird, J., Mandarino, J. A., Maresch, W. V., Nickel, E. H., Rock, N. M. S., Schumacher, J. C., Smith, D. C., Stephenson, N. C. N., Ungaretti, L., Whittaker, E. J. W., Youzhi, G. (1997). Nomenclature of amphiboles: report of the Subcommittee on Amphiboles of the International Mineralogical Association, Commission on New Minerals and Mineral Names. Canadian Mineralogist, 35, 219-246.

McLennan, S. M. (1989). Rare earth elements in sedimentary rocks: influence of provenance and sedimentary processes. In: B. R. Lipin, G. A. McKay (Eds.). Geochemistry and Mineralogy of rare earth elements: Reviews in Mineralogy, 21, 169-200.

Medeiros, V. C., Nascimento, M. A. L., Dantas, E. L., Cunha, A. L. C., (2012a). Programa Geologia do Brasil-PGB. Currais Novos. Folha SB.24-Z-B-II. Estados do Rio Grande do Norte e Paraiba. Carta Geológica. Recife: CPRM. 1 mapa colorido, $91,04 \times 65,79 \mathrm{~cm}$. Escala 1:100.000.

Medeiros, V. C., Nascimento, M. A. L., Galindo, A. C., Dantas, E. L. (2012b). Augen gnaisses riacianos no Domínio Rio Piranhas - Seridó, Província Borborema, Nordeste do Brasil. Geologia USP. Série Científica, 12(2), 3-14.

Medeiros, V. C., Nascimento, M. A. L., Sousa, D. C. (2010). Geologia. In: P. A. S. Pfaltzgraff, F. S. M. Torres. (Org.). Geodiversidade do Estado do Rio Grande do Norte, p. 15-38. Rio de Janeiro: CPRM.

Murray, R. W. (1994). Chemical criteria to identify the deposicional environment of chert: general principles and applications. Sedimentary Geology, 90, 213-232.

Planavsky, N., Bekker, A., Rouxel, O. J., Kamber, B., Hofmann, A., Knudsen, A., Lyons, T. W. (2010). Rare Earth Element and yttrium compositions of Archean and Paleoproterozoic $\mathrm{Fe}$ formations revisited: new perspectives on the significance and mechanisms of deposition. Geochimica et Cosmochimica Acta, 74(22), 6387-6405.

Raposo, F. O. (1996). Formações ferríferas e metassedimentos químicos de áreas selecionadas do quadrilátero ferrifero e suas relações com niveis rudáceos. Dissertação (Mestrado). Belo Horizonte: Instituto de Geociências - UFMG.

Roser, B. P., Korsch, R. J. (1986). Determination of tectonic setting of sandstone-mudstone suítes using $\mathrm{SiO} 2$ content and $\mathrm{K} 2 \mathrm{O} / \mathrm{Na} 2 \mathrm{O}$ ratio. Journal of Geology, 94, 635-650.

Sampaio, N. P. (2016). Construção de Banco de Dados de Minerais Brasileiros para Analisador Mineral Integrado, acoplado a Sistema MEV-EDS Automatizado. Dissertação (Mestrado). Ouro Preto: Escola de Minas - UFOP. 
Sial, A. N., Campos, M. S., Gaucher, C., Frei, R., Ferreira, V. P., Nascimento, R. C., Pimentel, M. M, Pereira, N. S., Rodler, A. (2015). Algoma-type Neoproterozoic BIFs and related marbles in the Seridó Belt (NE Brazil): REE, C, $\mathrm{O}, \mathrm{Cr}$ and $\mathrm{Sr}$ isotope evidence. Journal of South American Earth Sciences, 61, 33-52.

Silva Filho, C. V. R. (2012). Isótopos de Nd aplicados à datação direta de formações ferríferas paleoarqueanas do Maciço São José do Campestre, Rio Grande do Norte-RN. Dissertação (Mestrado). Brasília: Instituto de Geociências - UnB.

Souza, Z. S., Martin, H., Peucat, J. J., Jardim de Sá, E. F., Macedo, M. H. F. (2007). Calc-alkaline magmatism at the archean-proterozoic transition: the Caicó Complex basement (NE Brasil). Jounal of Petrology, 48(11), 2149-2185.

Spier, C. A., Oliveira, S. M. B., Sial, A. N., Rios, F. J. (2007). Geochemistry and genesis of the banded iron formations of the Cauê Formation, Quadrilátero Ferrifero, Minas Gerais, Brazil. Precambrian Research, 152, 170-206.
Trendall, A. F. (2002). The Significance of iron-formation in the Precambrian stratigraphic record. In: W. Altermann, P. L. Corcoran. Precambrian Sedimentary Environments: A modern approach to ancient depositional systems, 33-66. Bodmin: Blackwell Science.

Van Schmus, W. R., Brito Neves, B. B., William, I. S., Hackspacher, P. C., Fetter, A. H., Dantas, E. L., Babinski, M. (2003). The Seridó Group of NE Brazil, a late Neoproterozoic pre to syn-collisional basin in West Gondwana: isnsights from SHRIMP U-Pb detrial zircon ages and Sm-Nd crustal residence (TDM) ages. Precambrian Research, 127, 287-327.

Viehmann, S., Bau, M., Bühn, B., Dantas, E. L., Andrade, F. R. D., Walde, D. H. G. (2016). Geochemical characterisation of Neoproterozoic marine habitats: Evidence from trace elements and $\mathrm{Nd}$ isotopes in the Urucum iron and manganese formations, Brazil. Precambrian Research, 282, 74-96.

Wright, J., Schrader, H., Holser, W. T. (1987). Paleoredox variations in ancient oceans recorded by rare earth elements in fóssil apatite. Geochimica et Cosmochimica Acta, 51, 631-644. 